AL.2.1995-9

C. 2

\title{
An Identification Guide To Alberta Aquatic Plants
}
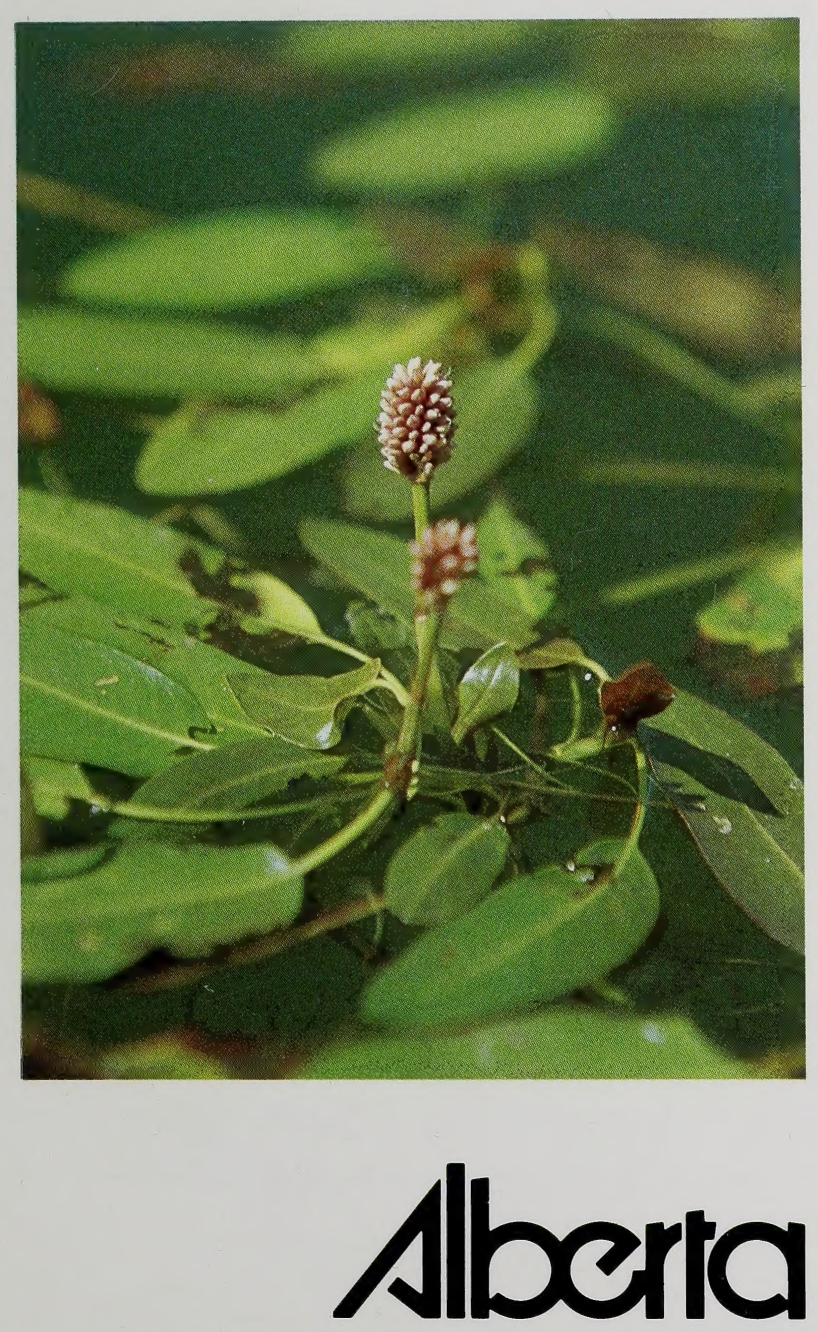
ENVIRONMENTAL PROTECTION 
Digitized by the Internet Archive in 2015

https://archive.org/details/identificationgu00burl 
AN IDENTIFICATION GUIDE TO ALBERTA

AQUATIC PLANTS

CANADIANA

JUL 261994

Compiled and Edited By

G. Robert Burland

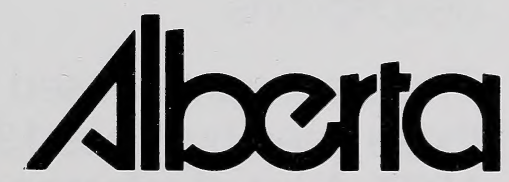

ENVIRONMENTAL PROTECTION Pesticide Management Branch 


\section{Preface.}

This guide is designed to provide a simplified means to identify aquatic plants. It is a field guide consisting of photographs and narrative descriptions of some of the common aquatic plants found in Alberta. The aquatic plants contained herein were chosen because of their common occurrence in Alberta. There are, of course, many more species present in the province, however, to include them all is beyond the scope of this publication.

The individual descriptions refer to easily distinguishable features that will permit identification to at least the genus level. A glossary is also provided in this guide to allay difficulties with unfamiliar terms used in the description. The photographs show the plants in a natural setting as would be viewed from a boat or from the shore.

Additional photographs of individual plants indicate structures referred to in the descriptions.

The plant names used in this guide are those used by Moss 1959, and Fassett 1977. A list of references is provided for those interested in more detailed and comprehensive information on aquatic plants. 
Appreciation is extended to Ms. Ann Hrabiwchuk, who began the preparation of this guide; to Dr. J.R. Allan, Dr. E.D. Allen, and Ms. P. Mitchell, for contributing photographs; and to the Aquatic Plant Management Committee of Alberta for providing suggestions and comments on the text. 
Notes 


\section{Contents}

TITLE PAGE

PREFACE

TABLE OF CONTENTS $\ldots . . \ldots \ldots \ldots . \vee v$

LIST OF REFERENCES ........... vii

GLOSSARY ...................... ix

INTRODUCTION .................... 1.0

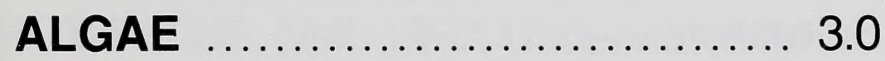

Filamentous Algae .............. 3.1

Planktonic Algae .................. 3.2

Macrophytic Algae .............. 3.3

FREE FLOATING PLANTS ....... 4.0

Lesser Duckweed ................. 4.1

Star Duckweed ..................... 4.2

Common Bladderwort ............. 4.3

SUBMERGENT PLANTS $\ldots \ldots \ldots \ldots .5 .0$

Canada Waterweed ................ 5.1

Mare's Tail ........................ 5.2

White Waterbuttercup ........... 5.3

Coontail ............................ 5.4

Northern Watermilfoil ............ 5.5

Richardson Pondweed ............ 5.6

Flat-stemmed Pondweed ......... 5.7

Small-leaf Pondweed ............. 5.8 
Large Sheath Pondweed .......... 5.9 Sago Pondweed ................. 5.10 Narrow-leaved Water-Plantain ... 5.11 Whitestem Pondweed ............ 5.12 FLOATING LEAVED PLANTS ..... 6.0 Yellow Water Lily .................. 6.1 Water Smartweed ................. 6.2 Floating-leaf Pondweed ........... 6.3 EMERGENT PLANTS ............. 7.0

Reed Grass ..................... 7.1

Common Cattail .................. 7.2 Bulrush ........................ 7.3 Rush ......................... 7.4 Arrowhead ........................ 7.5 Giant Bur-reed ................. 7.6 


\section{References}

BUDD, A.C. and K.F. Best. 1957. Wild plants of the Canadian prairies. Canada Department of Agriculture. Publication No. 983. New Edition.

FASSETT, Norman C. 1977. A manual of aquatic plants. The University of Wisconsin Press, Ltd., Madison, Wisconsin.

HOTCHKISS, Neil. 1967. Underwater and floating-leaved plants of the United States and Canada. Bureau of Sport Fisheries and Wildlife. Resource Publication 44, Washington, D.C.

MORGAN, Ann Haven. 1930. Field book of ponds and streams. G.P. Putnam's Sons, New York.

MOSS, E.H. 1959. Flora of Alberta. University of Toronto Press, Toronto.

OTTO, N.E. and T.R. Bartley. 1965. Aquatic pests on irrigation systems. Identification guide. A Water Resource Technical Publication. U.S. Government Printing Office, Washington, D.C.

PRESCOTT, G.W. 1969. The aquatic plants. Wm. C. Brown Company, Dubuque, lowa. 


\section{Glossary}

APEX: tip of a stem, branch or root

AXIL: space formed by the angle between a leaf or branch and the stem

BLADE: the flattened or broad portion of a leaf

BRACT: a scale or leaf-like structure extending under a flower or flower cluster

BUDDING: a form of reproduction where the parent plant produces offspring vegetatively

BULBLET: a small bulb

CREEPING RHIZOME: a rhizome growing on or near the soil surface

EMERGENT: extending above the water surface

FILAMENTOUS: thread-like

FLOATING LEAVED: leaves floating but rooted

FREE FLOATING: plant floating but unattached

GREGARIOUS: individuals living in groups

HEAD: a dense flower cluster on a short common axis

HYDROSOIL: soil covered by water 
IRREGULAR (flower): having one or more floral organs of a series, i.e. petals, unequal in shape or size

LANCEOLATE: lance-shaped; wide at the base and pointed at the tip

LATERAL: on the side of

LEAFLET: a division of a compound leaf

LINEAR: narrow and long with parallel sides

MACROPHYTE: a large or fairly large plant; easily seen with the naked eye

NODE: a level on the stem from which leaves or roots may arise

OBLONG: oval but with broadly rounded ends and nearly parallel sides

PANNICLE: a compound raceme; a branched flower cluster, lowermost branches longer

PEDUNCLE: a flower stalk having a single flower or flower cluster

PERFECT (flower): complete flower; having both male and female organs, petals and sepals

PETIOLE: the stalk of a leaf

PINNATE: a compound leaf with leaflets arranged on both sides of a common axis

PISTIL: female portion of a flower 
PLANKTONIC: suspended in the water column

RACEME: a group of stalked flowers arranged on a common axis

RHIZOME: a root producing stem, commonly underground

ROOTLET: a small root

RUNNER: a horizontal branch extending along the ground and giving rise to new roots and plants

SAGITTATE: shaped like an arrowhead, lobes directed downward

SCAPE: a flowering stalk without leaves originating at or near the ground

SESSILE: without a stalk

SHEATH: a collar-like outgrowth at a node, or the basal portion of a leaf wrapped around the stem

SPIKE: a group of flowers sessile or nearly so growing close together on a longitudinal axis

STAMEN: male portion of a flower

STIPULE: an outgrowth at the base of a leaf blade or petiole

SUBMERGENT: growing under water

TERMINAL: at the end of a stem, branch or root

THALLUS: a plant body without true roots, stems or leaves 
TUBER: a thickened underground branch or part of a branch capable of producing new plants

\section{UNISEXUAL: of one sex}

WHORL: a group of three or more like organs such as leaves or flowers arising from a single node

WINTER BUD: a small hardened grouping of close leaves surviving the rest of the plant over winter and capable of producing a new plant in spring 


\section{Introduction}

An aquatic plant can be defined as a plant which, under normal circumstances, carries out its life cycle while being at least partially submerged in water. There are many forms of aquatic plants ranging from the microscopic algae to the common cattails which may reach 2.5 meters in height.

The algae are the most primitive of the aquatic plants, having no vascular system and lacking true stems, leaves or rootș. For the most part, individual alga cannot be identified without detailed microscopic examination. For this reason, and because of the vast number of algal species, this guide will deal with the algae only in broad terms.

Aquatic macrophytes (individual plants easily visible to the naked eye) are treated more specifically here because many of them may be readily identified in the field and this guide is designed for that use.

These plants can, in general, be classified as emergent, floating leaved, submergent or free floating depending on their growth habits and basic structure.

Each type of aquatic macrophyte will occupy a more or less distinct zone in the aquatic environment (Fig. 1) . Growing close to shore in shallow water are the emergent 
plants. Emergent aquatic vegetation characteristically grows with the base of the stem beneath the water surface while the remainder of the plant (stem, leaves and flowers) extend into the air. Examples of emergent vegetation are cattails and bulrushes. Occasionally, an aquatic plant classified as an emergent will be found rooted in exposed soil provided that the water table is sufficiently high.

In shallow water protected from wind and wave action, floating leaved plants such as water lily can be found. Floating leaved plants are rooted in the underwater soil (hydrosoil) and have long stems or petioles connecting to broad leaves floating on or near the water surface.

Moderately shallow to fairly deep water is inhabited by submergent aquatic vegetation. These plants grow entirely beneath the water surface, and are rooted or otherwise attached to the bottom substrate. Depending on the water for structural support, submergent plants are usually flaccid when brought into the air, and lack substance when dried. Examples of submergent aquatic plants include water milfoil and pondweed.

The remaining forms of aquatic vegetation belong in the free floating category. Free floating plants exist at or near the water surface and are not attached to any object. Moved about freely by wind or wave action, they occupy no distinct zone in the aquatic 
environment. A good example of free floating vegetation is duckweed.

In using this guide to identify an aquatic plant, first determine to which of the above categories the particular plant belongs. Turn to the appropriate section in the guide and match the specimen with one of the photographs. Use the descriptions in conjunction with the photographs to verify your identification. 


\section{Filamentous Algae}

\section{DESCRIPTION}

These freshwater algae are characterized by long threads or filaments of narrow cells attached to one another, end to end. These filaments are sometimes branched, forming a tuft attached to stones (they have no structure comparable to a root). In early spring they grow on the pond bottom rising to the surface during hot, sunny weather to form a bubble-filled scum. Determination of various forms of filamentous algae should be verified by microscopic examination. Common genera of filamentous algae include Cladophora and Spirogyra. 


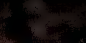

\section{$=$}

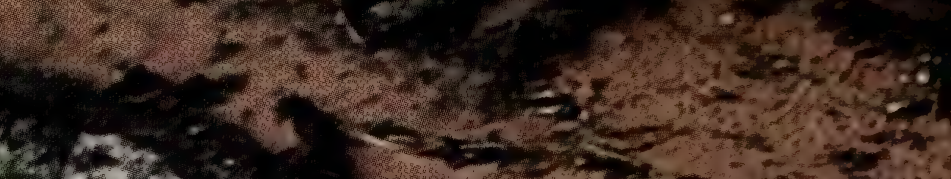

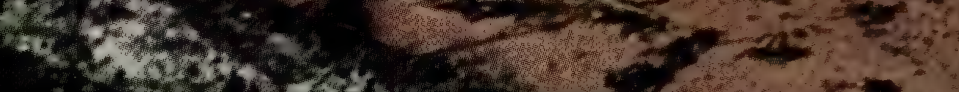

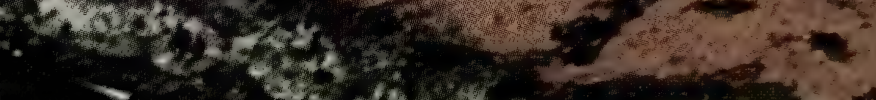
$4 \times$

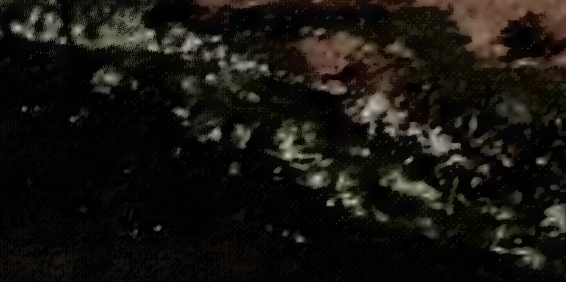

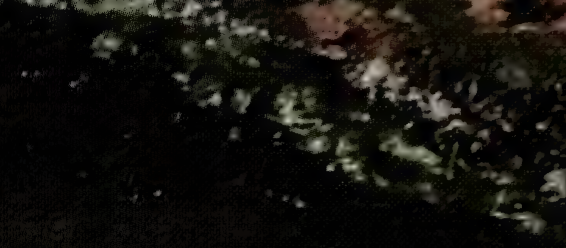

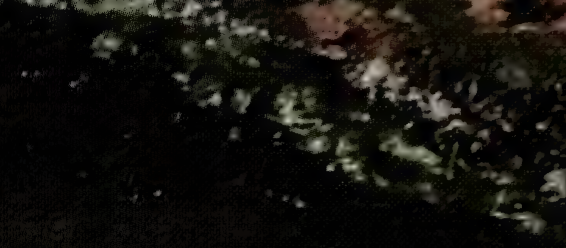

$$
\begin{aligned}
& -2
\end{aligned}
$$

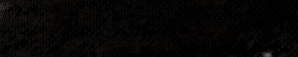

6

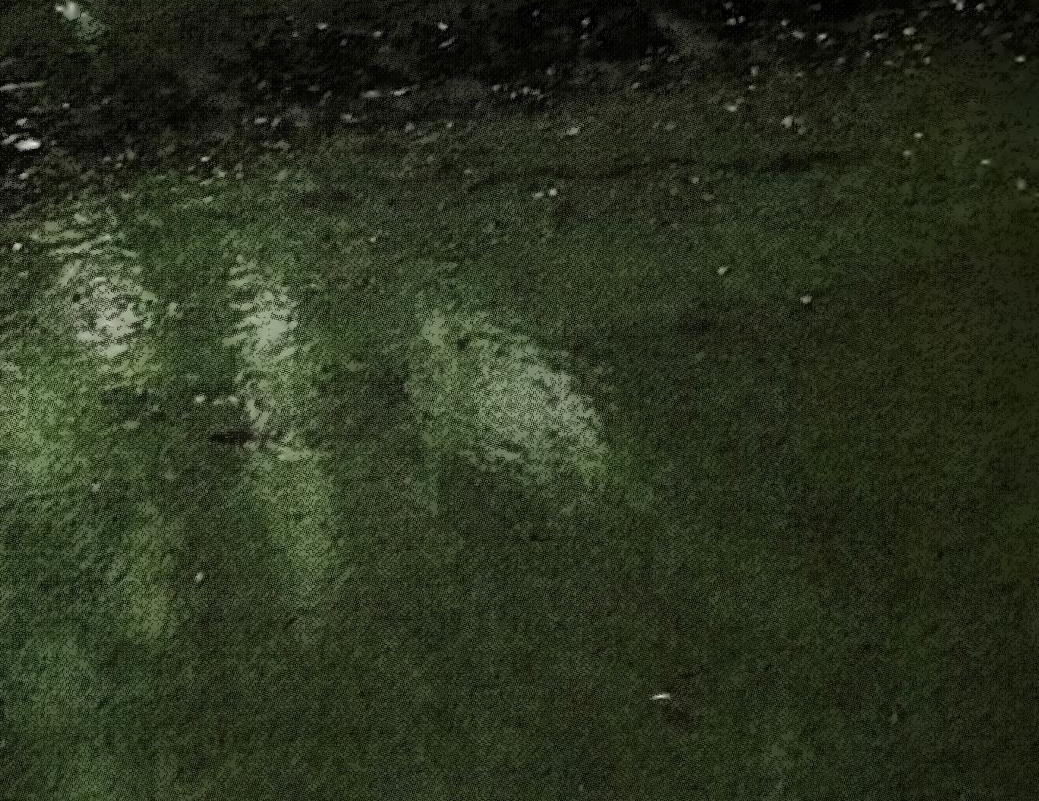




\section{Planktonic Algae}

\section{DESCRIPTION}

These microscopic organisms may be single or many-celled, and commonly form simple chains or clumps due to their gregarious nature. They appear green, blue-green or brown in colour and float freely within the water column. The growth of certain forms of this type of algae may become so great that the water may take on a thick pea soup appearance. "Algae blooms" collect at the surface of the water during periods of calm and are concentrated in-shore by wind. As these "algae blooms" die off and decay, the resulting oxygen depletion of the water may cause summerkill of fish populations. Some species of planktonic algae release toxins as they decay, occasionally rendering the water poisonous to livestock and wildlife. Other species may impart tastes and odors to water, making it undesirable for consumption. Types of planktonic algae which may form "algae blooms" in ponds and lakes include Aphanizomenon, Microcystis, and Anabaena. 
r.

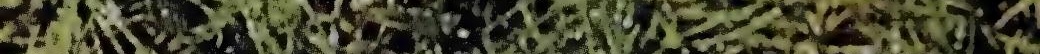

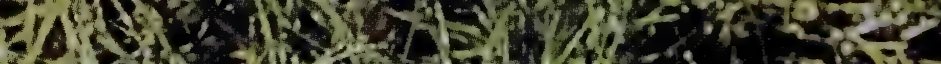

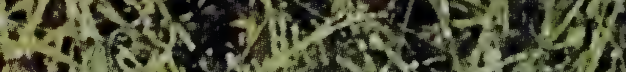

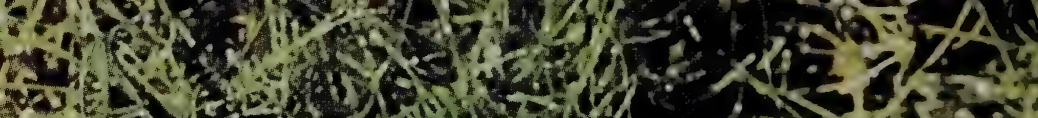

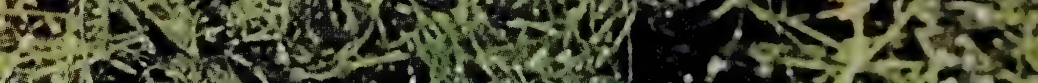

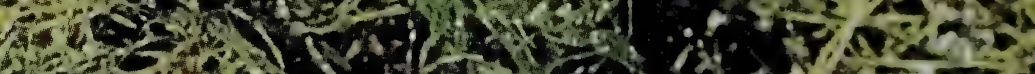

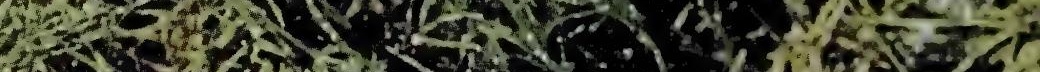

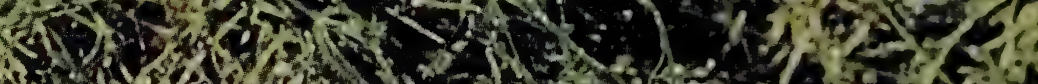

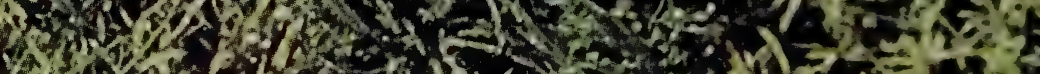

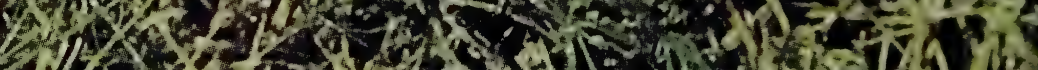

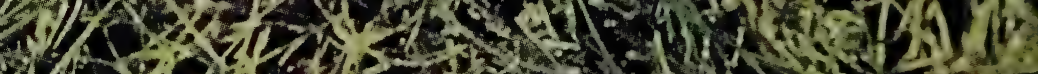

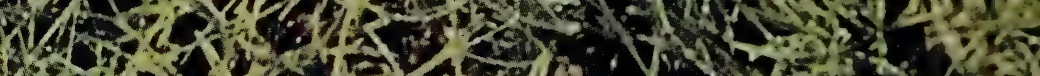

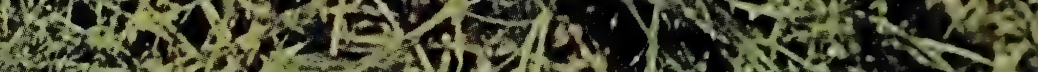

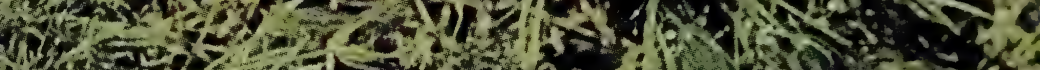

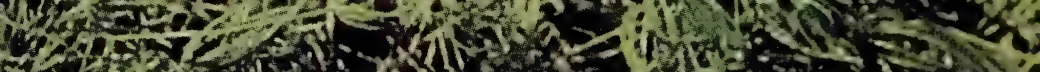

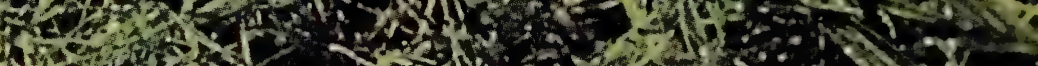

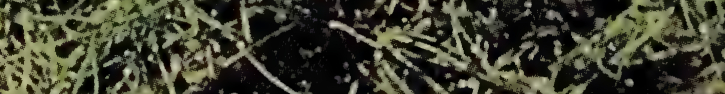

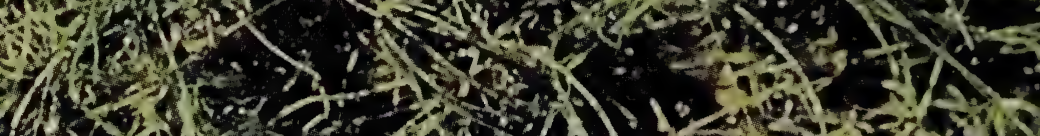

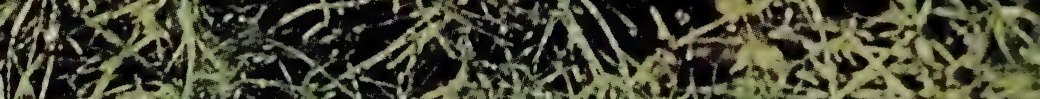

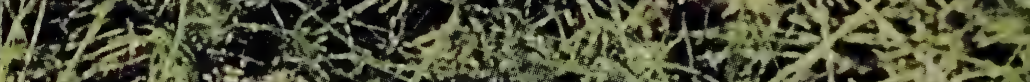

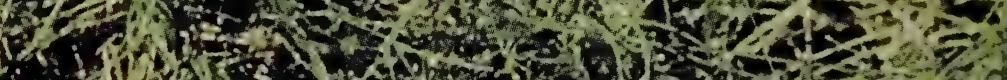

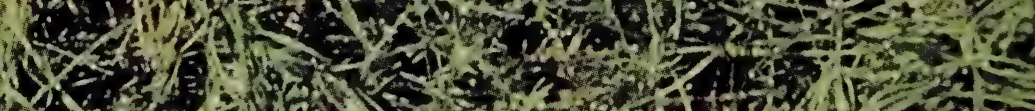

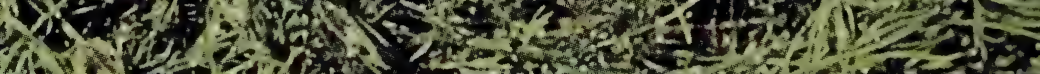

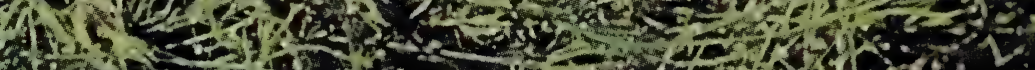

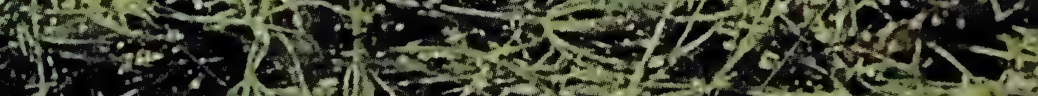

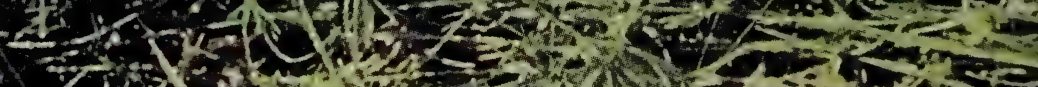

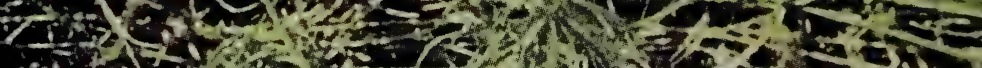

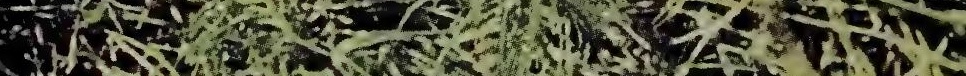

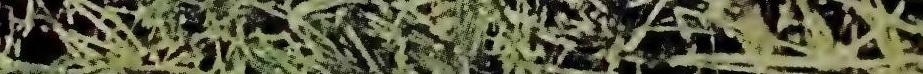

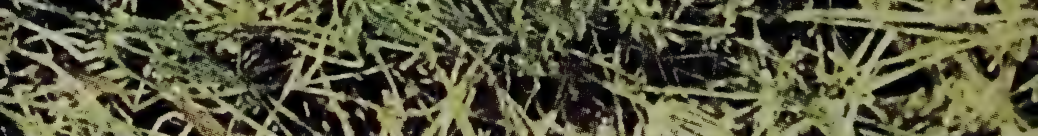

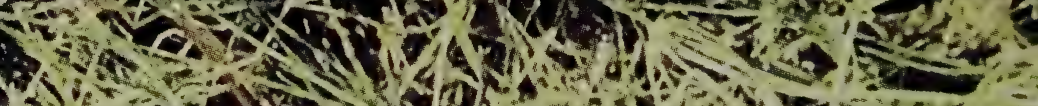

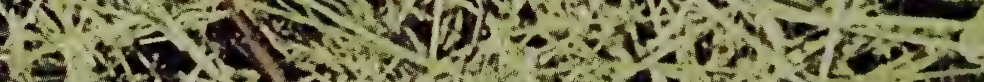

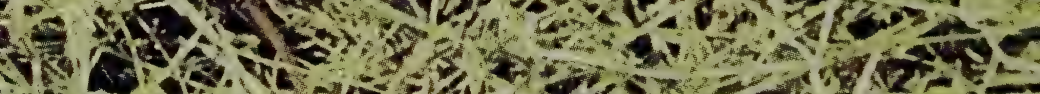

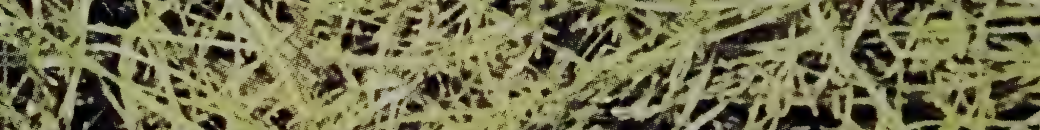

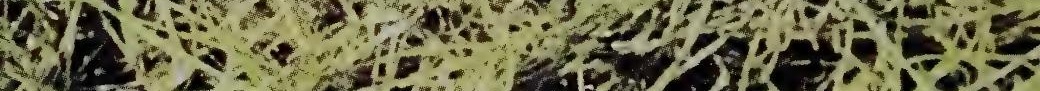

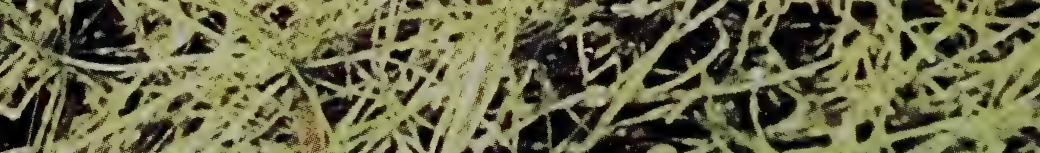

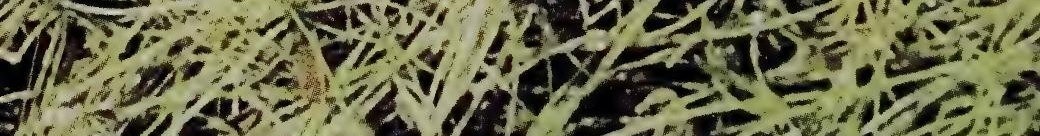

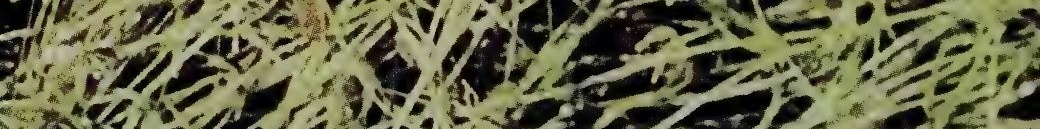

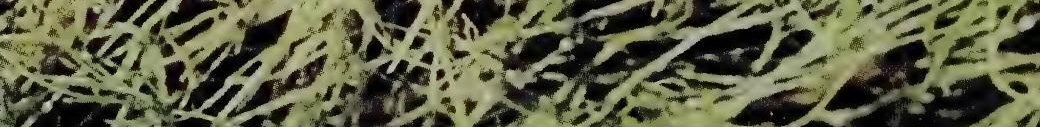




\section{Macrophytic Algae}

\section{DESCRIPTION}

Macrophytic algae can grow sufficiently large enough that individual plants may be seen readily without the aid of a microscope. A macrophytic algae which is prevalent throughout Alberta is Chara.

Members of the genus Chara are also known as stoneworts because of a crusty lime coating which is deposited on their 'stems' and 'leaves.' They are green or grey-green in color and often emit a musky, skunk-like odor.

The stem-like axis of Chara bears whorls of branches and forked cylindrical 'leaves.'

Reproduction may occur sexually by fruiting bodies found on the 'leaf' filaments, or vegetatively by star-shaped aggregates of cells on the lower 'stem' nodes, and outgrowths from the 'stem' nodes.

Chara will be found in hard water or alkaline lakes and in slow moving streams in which calcium is abundant. Thick mats of Chara may be encountered covering the bottom in shallow or very deep water. Chara provides a habitat for a wide variety of aquatic animals which act as food for fish. 
FREE FLOATING

AQUATIC PLANTS

4.0 


\section{Lemna minor $\mathrm{L}$.}

\section{OTHER NAMES}

Common Duckweed

\section{DESCRIPTION}

Flowers: rarely present; unisexual; male flower of single stamen, female flower of single pistil; borne on the side or upper surface of the thallus

Plant Body: no true leaves or stems present, plant body is in the form of a flat thallus; 2 - $5 \mathrm{~mm}$ in length

Roots: single rootlet borne on the underside of the thallus

\section{NOTES}

Reproduction: rarely by seeds; predominantly by budding; overwinter as bulblets formed by the thalli which sink to the bottom in fall and surface in spring

Habitat: floating on the surface of shallow ponds, marshes and pools; common throughout Alberta

Ecology: eaten by waterfowl; provides shade and cover for fish and aquatic invertebrates; in overabundance may alter existing habitat by shading out other forms of vegetation 


\section{Star Duckweed}

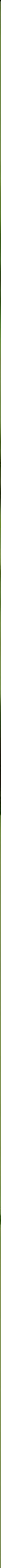




\section{Lemna trisulca $L$.}

\section{OTHER NAMES}

Ivy Leaved Duckweed

\section{DESCRIPTION}

Flowers: rarely present; unisexual; male flower of single stamen; female flower of single pistil

Plant Body: a flat thallus; individual thalli often joined together forming $T$-shaped cross arrangements; thalli $6-10 \mathrm{~mm}$ long

Roots: single rootlet borne on the underside of the thallus

\section{NOTES}

Reproduction: primarily by budding; seeds are rare; overwinter as bulblets formed by thalli which sink to the bottom in fall

Habitat: floating at or just below the water surface; common throughout Alberta in shallow ponds, marshes and pools

Ecology: eaten by waterfowl; provides cover for fish and aquatic invertebrates, often found in association with Lesser duckweed 


\section{Common Bladdenwort}

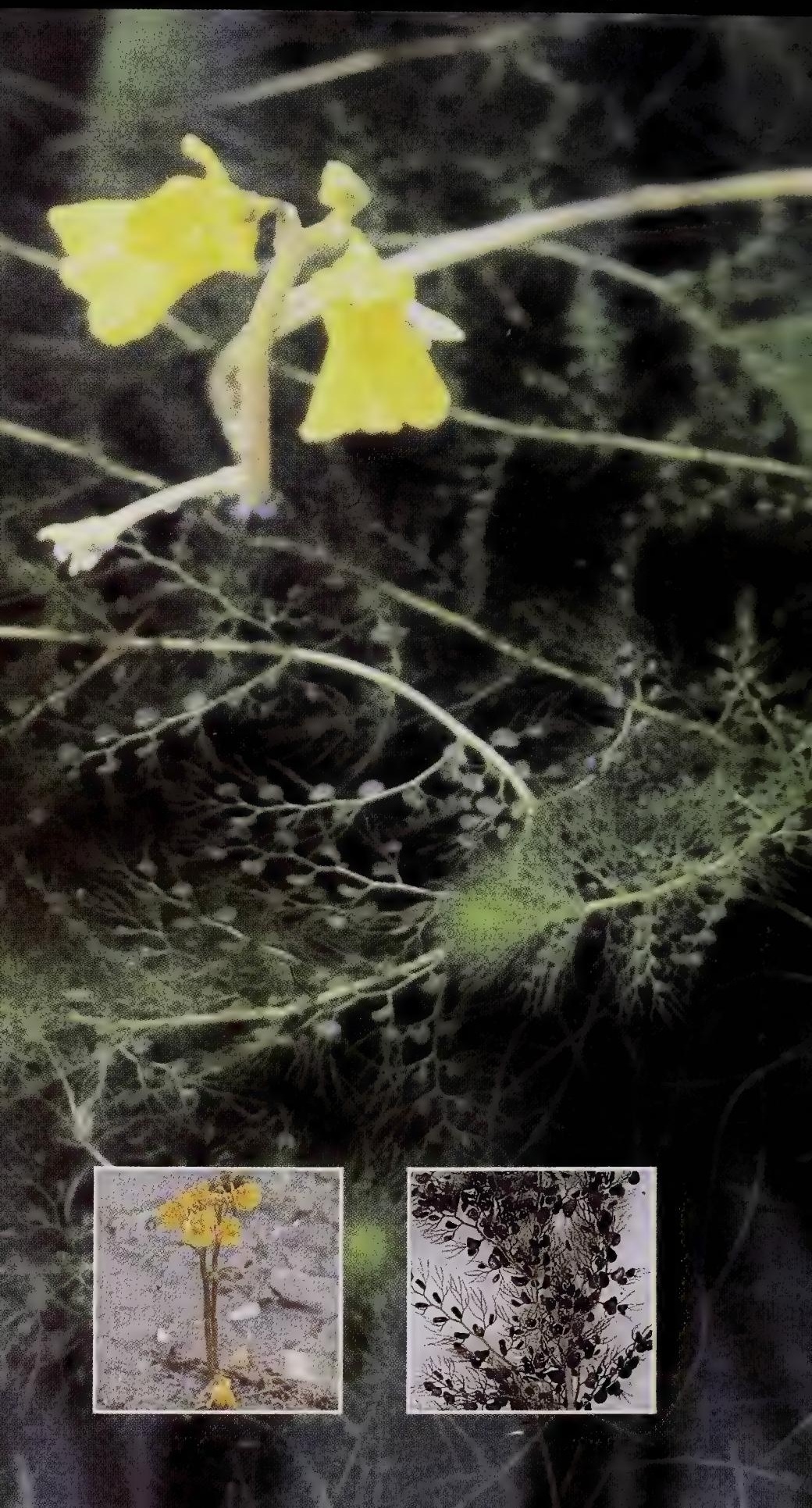




\section{Utricularia vulgaris L.}

\section{DESCRIPTION}

Flowers: yellow; irregular; extending above the water surface on long stalks

Leaves: having numerous bladders $3-5$ $\mathrm{mm}$ long; finely cut into numerous threadlike divisions

Stems: having dense foliage, $5-7 \mathrm{~mm}$ thick

Roots: lacking

\section{NOTES}

Reproduction: seeds; winter buds formed at shoot apices

Habitat: lakes, sloughs and ditches throughout Alberta; floating near the surface in quiet water

Ecology: eaten by waterfowl; provides good cover for fish; the bladders of this plant open to trap small aquatic animals which are used for nutrition 


$$
\begin{array}{r}
\text { SUBMERGENT } \\
\text { AQUATIC PLANTS }
\end{array}
$$




\section{Elodea canadensis Mich $\mathrm{x}$.}

\section{OTHER NAMES}

Water Thyme, Ditch Moss

\section{DESCRIPTION}

Flowers: unisexual, male and female on separate plants, the female plant is seen more commonly; the female flower reaches the surface on a long slender stalk; the male flower is borne on a shorter stalk which separates from the plant allowing the flower to rise to the surface and meet the female

Leaves: dark green, translucent; small and narrow, 1 - $3 \mathrm{~mm}$ wide, 10 - $15 \mathrm{~mm}$ long; commonly arranged in whorls of three Stems: branching; ranging in length from $1-3 \mathrm{~mm}$

Roots: may arise from the stem nodes; the plant is usually rooted in the hydrosoil but may survive if floating

\section{NOTES}

Reproduction: primarily by winter buds, rarely by seeds

Habitat: may produce dense stands in shallow areas of lakes, sloughs and slow moving streams

Ecology: provides shelter for a wide variety of aquatic organisms; eaten by waterfowl and muskrat; an efficient oxygenator of water 


\section{Mare's Tail}

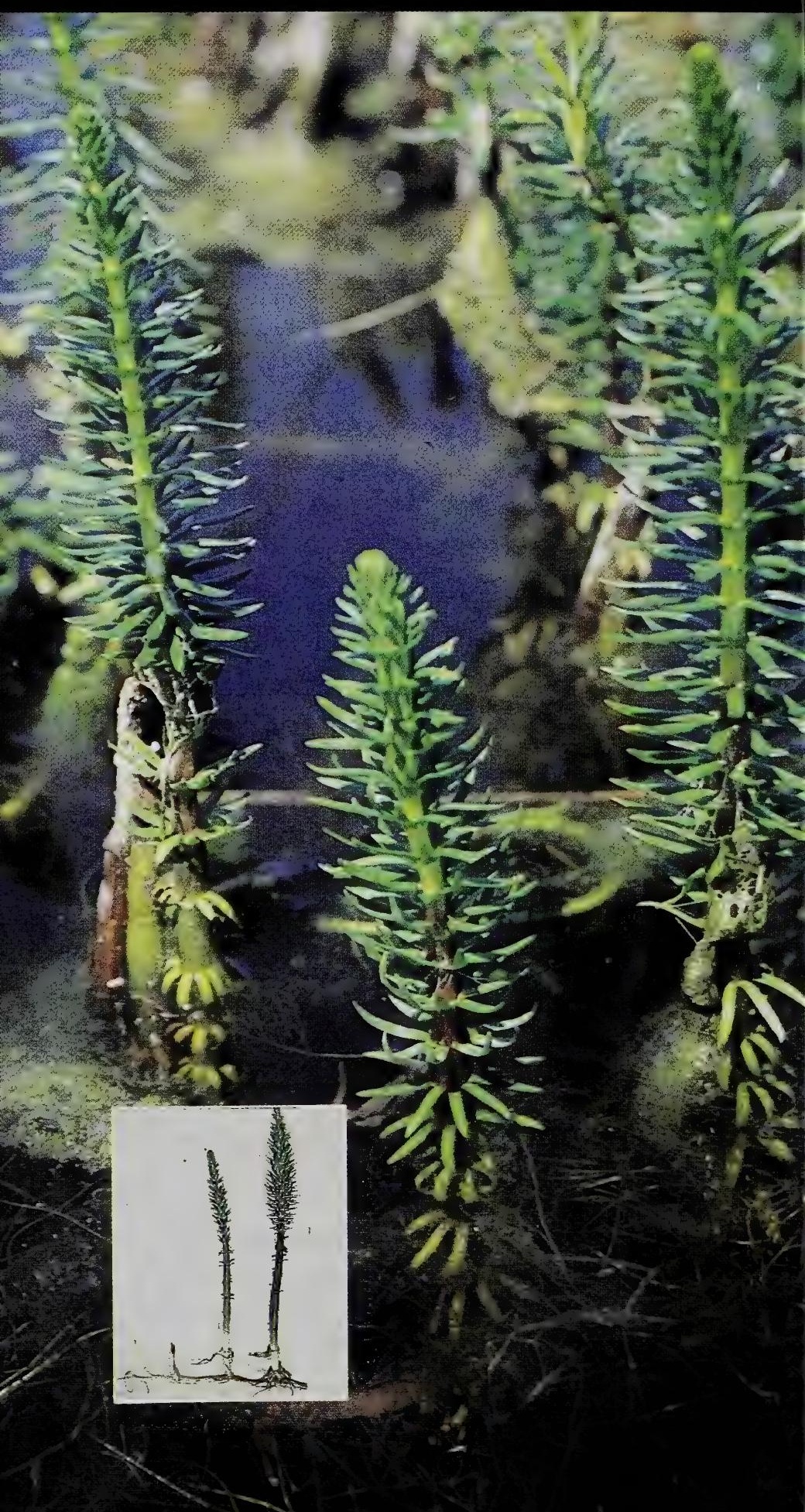




\section{Hippurus vulgaris L.}

\section{DESCRIPTION}

Flowers: green; sessile; borne in the leaf axils on emergent portion of the plant

Leaves: sessile; $1-3 \mathrm{~cm}$ long; linear and pointed, in whorls of 6 to 12 leaves; submerged leaves flaccid, emerged leaves firm

Stems: unbranched; extending from a creeping rhizome; emerging above the surface

\section{NOTES}

Reproduction: seeds, proliferation of the rhizome

Habitat: largely submergent in sheltered waters throughout Alberta; may also be found growing in muddy, exposed soils

Ecology: seeds and leaves eaten by waterfowl; underwater foliage is inhabited by aquatic invertebrates 


\section{White Waterbuttercup}

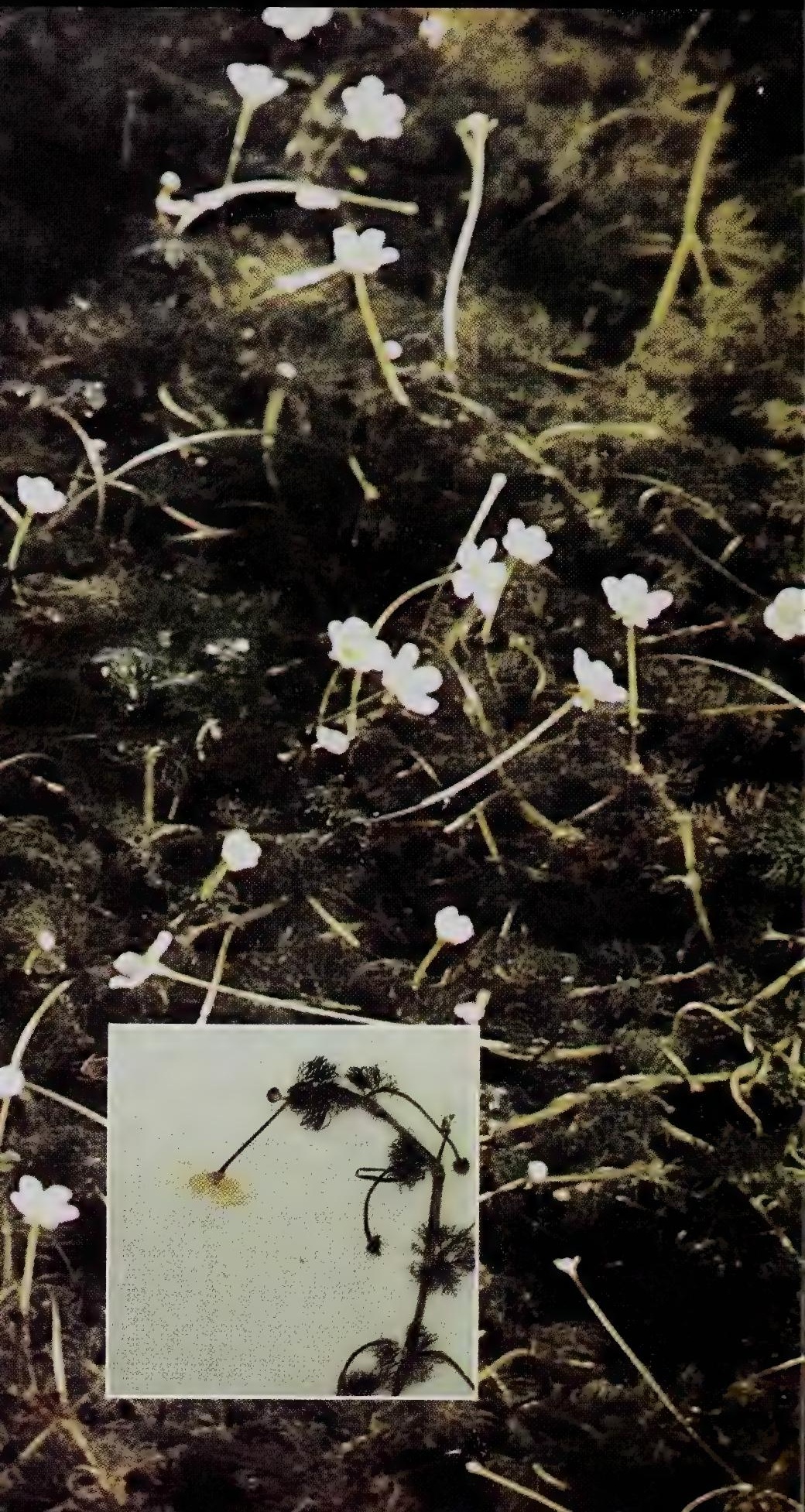




\section{Ranunculus circinatus Sibth}

\section{OTHER NAMES}

Water Crowfoot

\section{DESCRIPTION}

Flowers: produced on or above the water surface; white in color; petals $5-9 \mathrm{~mm}$ long

Leaves: sessile; finely cut into many threadlike divisions; fairly stiff, retaining shape when taken from the water

Stems: branched

\section{NOTES}

Reproduction: seeds

Habitat: commonly found in sloughs, lakes and streams in Alberta; does not readily tolerate poor water quality

Ecology: may grow in over abundance, forming thick mats on the water surface 


\section{Coontail}

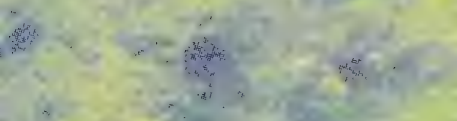

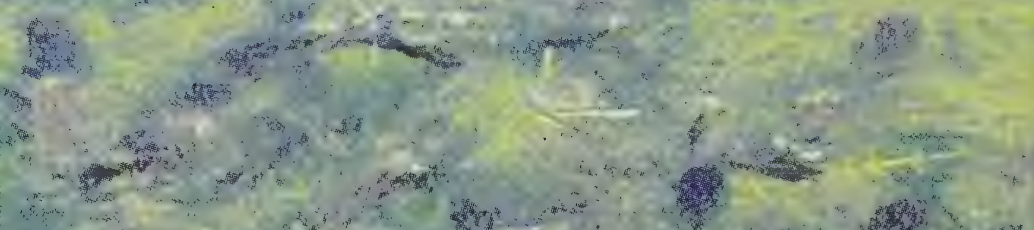

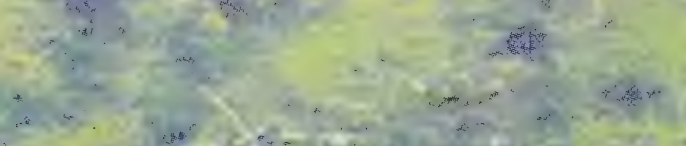

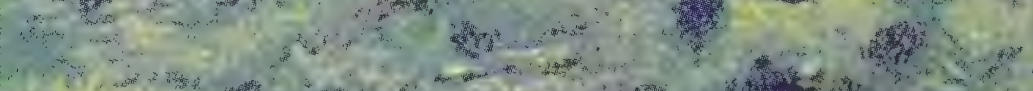

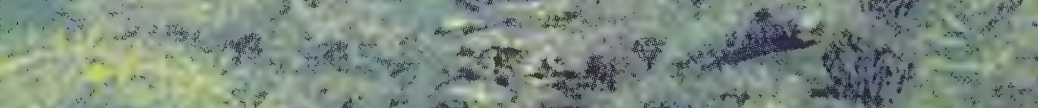

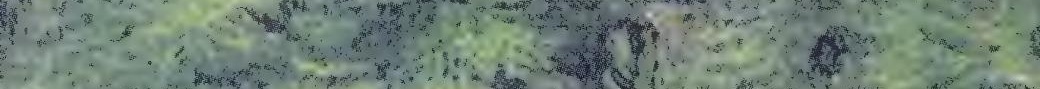

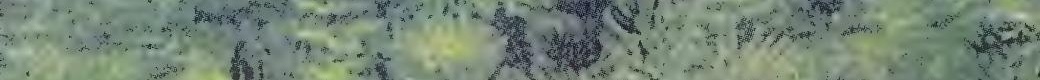

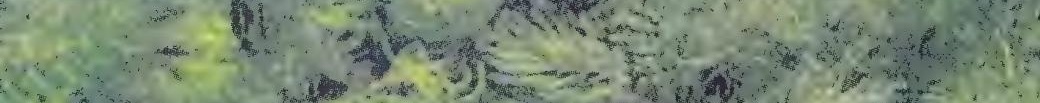

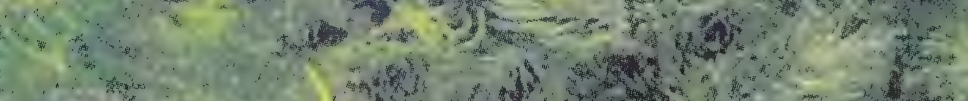

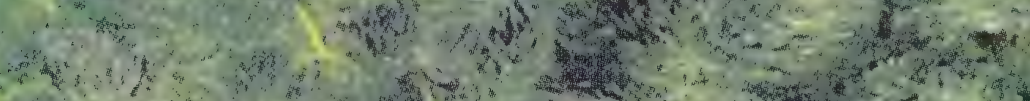
a

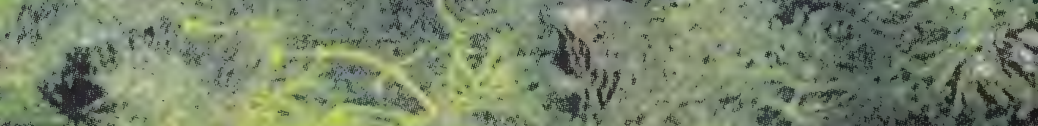

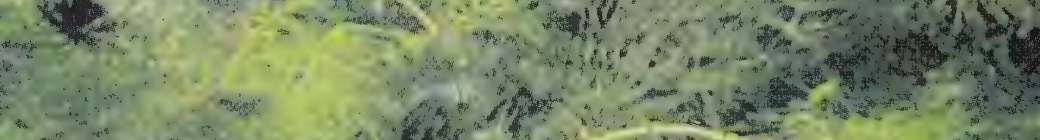

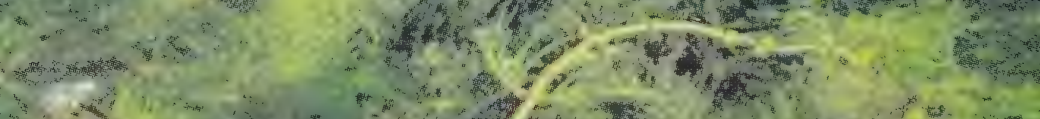

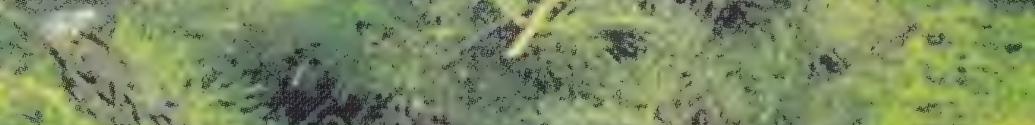

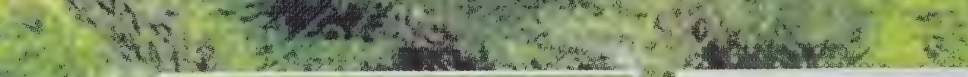

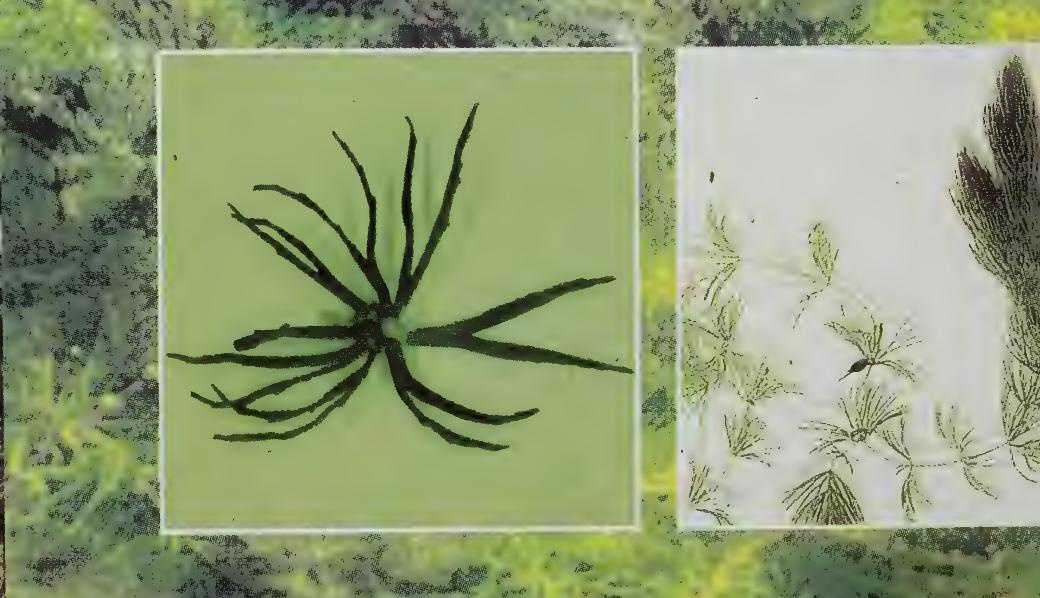
- 2.

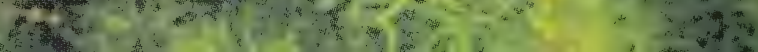




\section{Ceratophyllum demersum L.}

\section{OTHER NAMES}

Hornwort

\section{DESCRIPTION}

Flowers: minute; sessile in the leaf axils

Leaves: in whorls of $5-12$ leaves; whorls variably spaced on the stem, crowding towards the tip, giving a "coontail" appearance; each leaf forked into 2 or 4 toothed divisions; often stiff and coarse in texture because of lime deposits

Stems: branching; $30 \mathrm{~cm}-1.5 \mathrm{~m}$ in length Roots: usually lacking

\section{NOTES}

Reproduction: rarely by seeds; winter buds forming on shoot apices

Habitat: embedded in the hydrosoil early in the season, later existing unattached

Ecology: eaten by muskrat and waterfowl; shelters young fish and supports aquatic insect life; moderately efficient as an aerator 


\section{wity

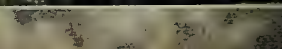 \\ Northern Watermilfoil}

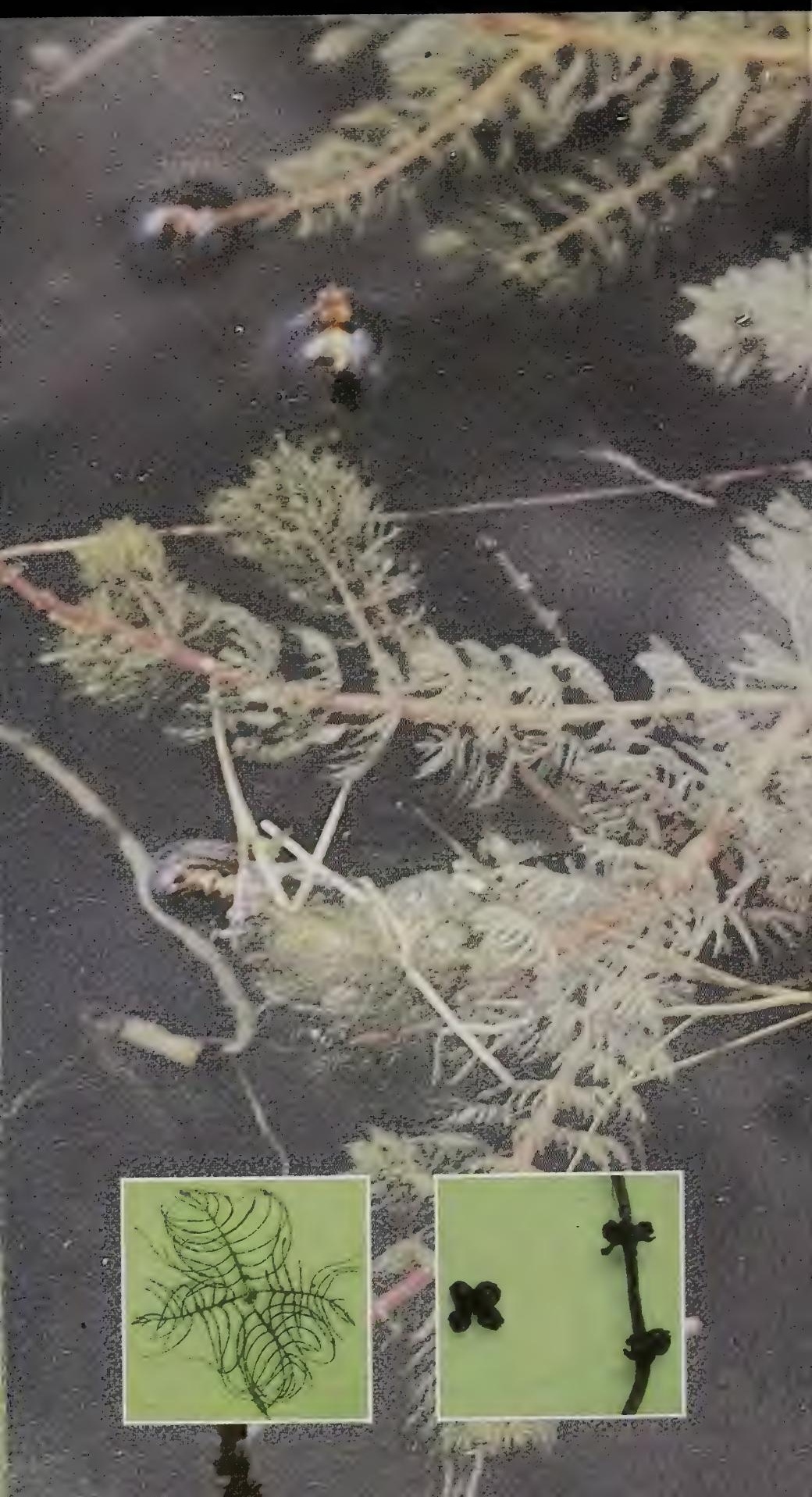




\section{Myriophyllum exalbescens Fern.}

\section{DESCRIPTION}

Flowers: in whorls which are variably spaced on a terminal emergent spike; floral bracts rarely as long as the fruits

Leaves: feather-like; whorled, usually four to a whorl; $1-3 \mathrm{~cm}$ long; pinnate, $12-20$ leaflets per leaf

Stems: branching; purplish or reddish in color, commonly about $1 \mathrm{~m}$ long

Roots: spirally twisted

\section{NOTES}

Reproduction: seeds, plant fragments; winter buds

Habitat: sloughs, lakes, and streams throughout Alberta; at a variety of depths

Ecology: important as food for muskrat and moose as well as waterfowl; harbors fish food organisms 


\section{Richardson Pondweed}

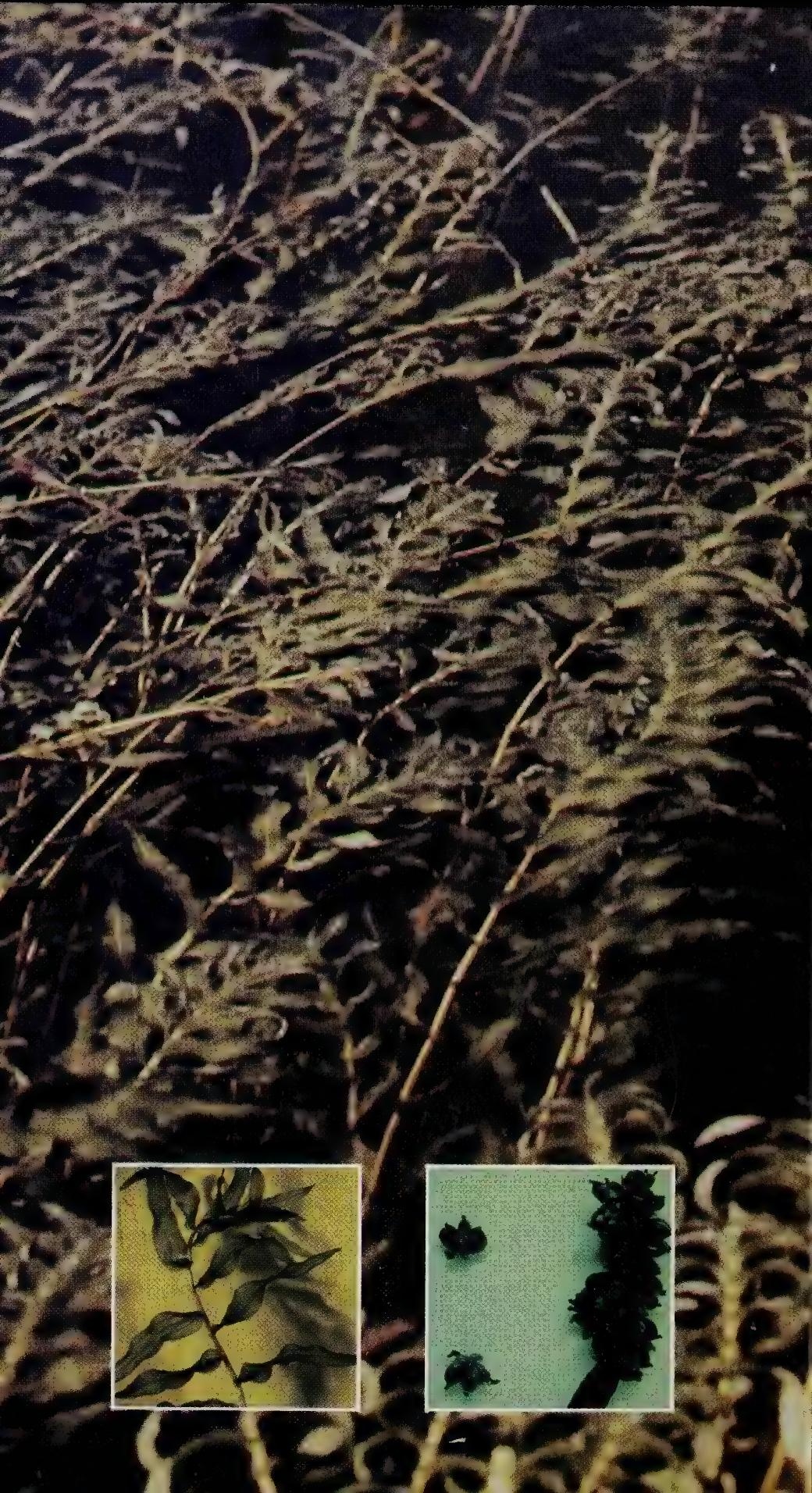




\section{Potamogeton richardsonif (Benn.) Rydb.}

\section{OTHER NAMES}

Clasping Leaf Pondweed

\section{DESCRIPTION}

Flowers: produced in thick spikes which may emerge

Leaves: all submerged, $3-12 \mathrm{~cm}$ long, lessening in length towards tip of stem; oval to linear; clasping stem at points of attachment; sessile; margins wavy

Stems: branched; extending from unspotted rhizomes

\section{NOTES}

Reproduction: seeds; proliferation of the rhizome

Habitat: very common in Alberta; inhabiting lakes, ponds and slow moving streams

Ecology: provides good habitat for aquatic organisms; all or part of the plant is eaten by ducks, shorebirds, muskrat, beaver and moose 


\section{Flat-Stemmed Pondweed}

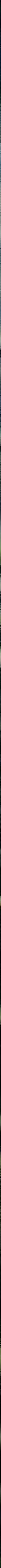




\section{Potamogeton zosteriformis Fern.}

\section{DESCRIPTION}

Flowers: forming a terminal spike; emerging

Leaves: linear, $10-20 \mathrm{~cm}$ long; with prominent midvein; nonsheathing base; stipules well developed, fibrous, $1-3 \mathrm{~cm}$ long

Stems: flattened; several times as wide as thick; branching

\section{NOTES}

Reproduction: predominantly by tubers and winter buds; seeds

Habitat: common to lakes, sloughs and slow moving streams of Alberta

Ecology: tubers and seeds are important as duck food 


\section{Small-Leaf Pondweed}




\section{Potamogeton pusillus L.}

\section{DESCRIPTION}

Flowers: forming an emergent spike

Leaves: linear, $1-8 \mathrm{~cm}$ long, $.3-1.5 \mathrm{~mm}$ wide; with three veins, midvein prominent

Stems: threadlike; branched

\section{NOTES}

Reproduction: seeds; winter buds

Habitat: growing in clumps; usually in deeper water (depths of $2-3$ meters); common in Alberta

Ecology: provides a good source of food for waterfowl; cover for fish 


\section{Large-Sheath Pondweed}
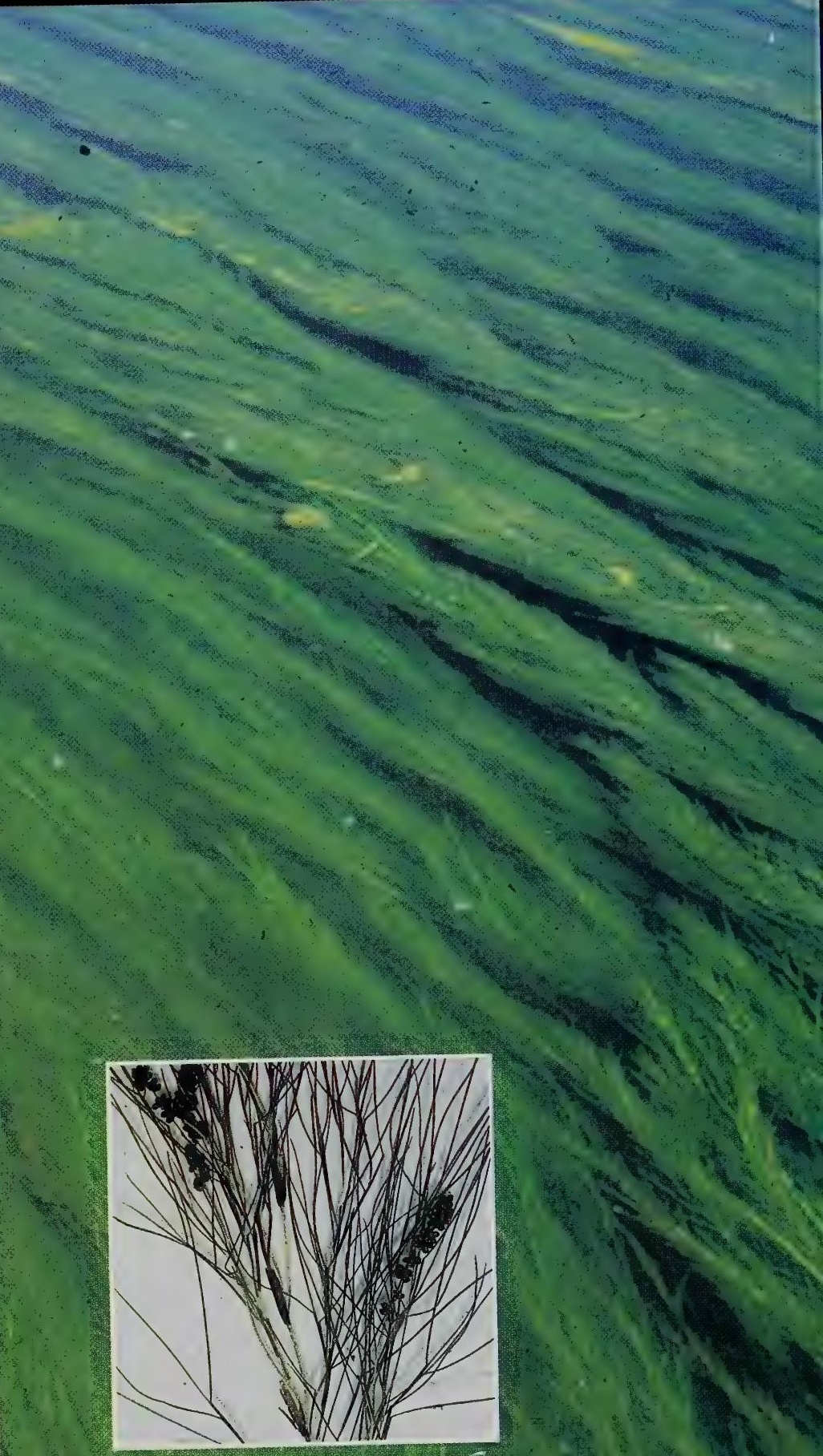


\section{Potamogeton vaginatus Turcz.}

\section{OTHER NAMES}

Giant Pondweed

\section{DESCRIPTION}

Flowers: forming a $3-8 \mathrm{~cm}$ long spike

Leaves: long $(10-40 \mathrm{~cm})$ and slender; coarse in texture; lower leaves have a broadened stipular sheath ( $2-5 \mathrm{~cm}$ long) which is much wider than the stem

Stems: branching; extending from a rhizome; relatively thick compared to the leaves

\section{NOTES}

Reproduction: seeds, proliferation of the rhizome

Habitat: lakes, larger sloughs and slow moving streams; common in Alberta

Ecology: may form dense stands under suitable conditions; can become problematical because of its large size 


\section{Sago Pondweed}

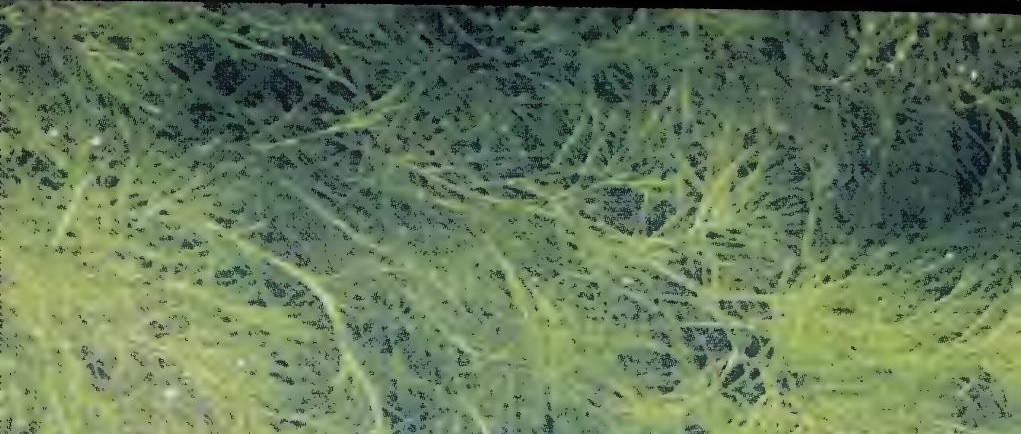

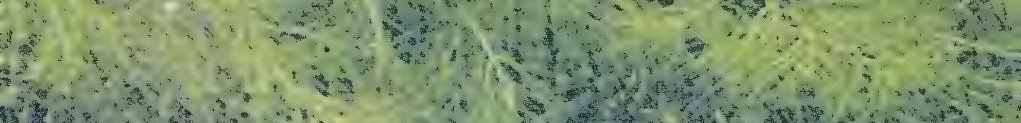

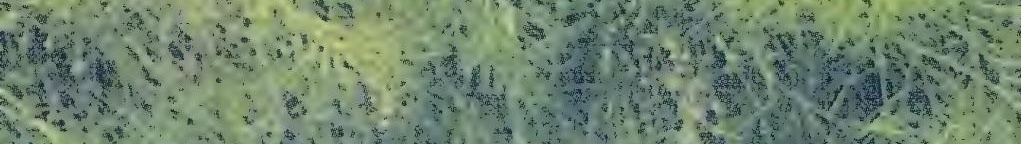

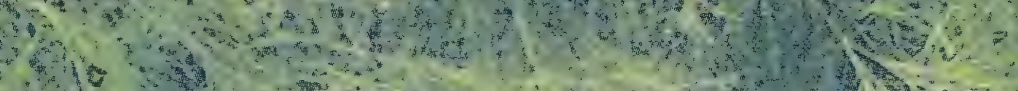

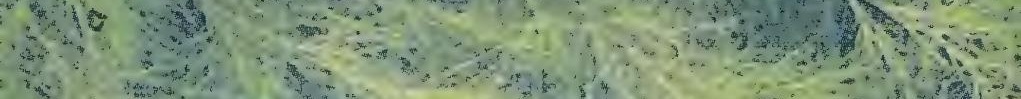

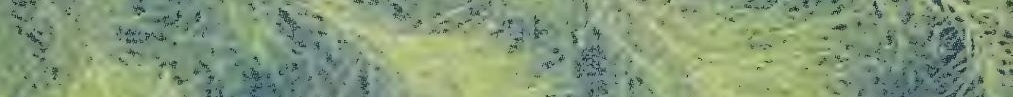
$\therefore$ (19)

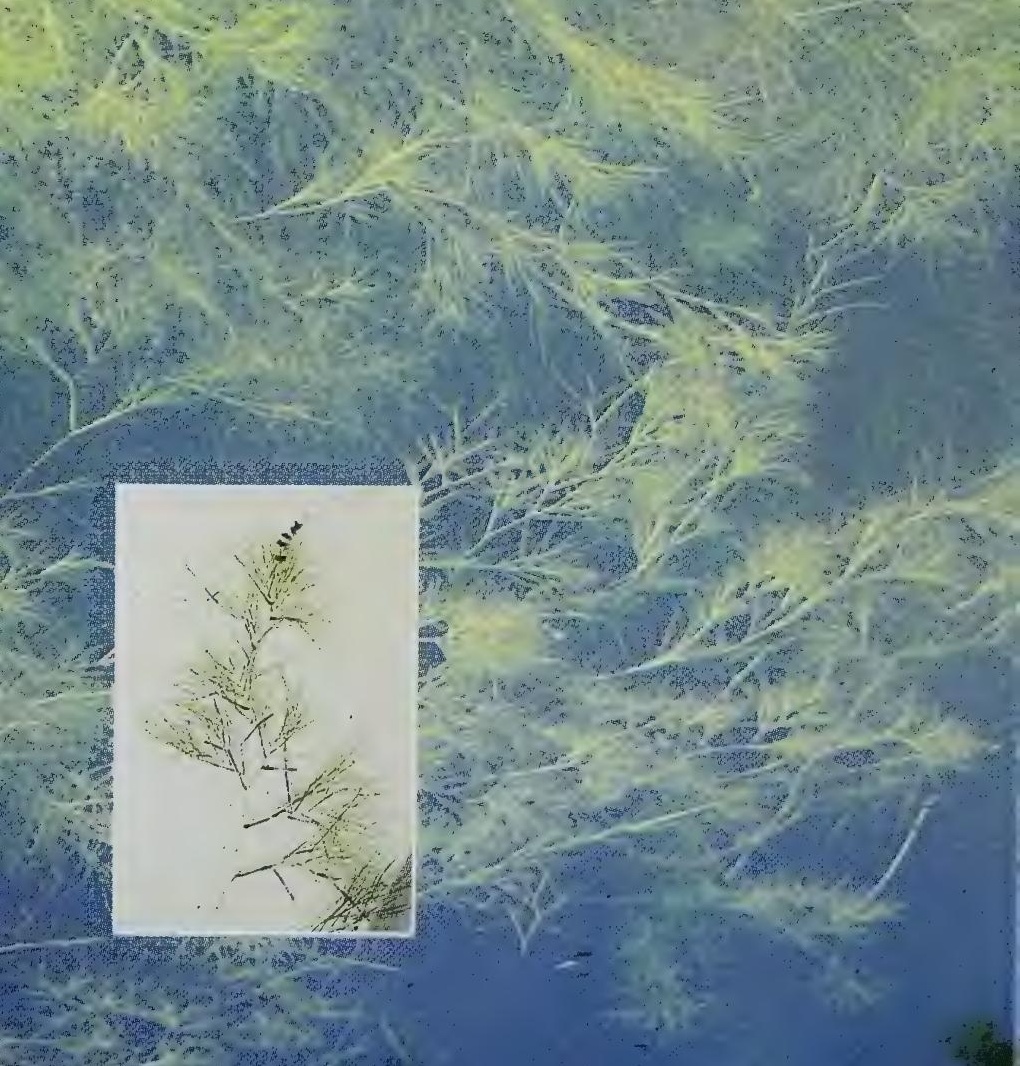




\section{Potamogeton pectinatus $L$.}

\section{OTHER NAMES}

Bushy Pondweed

\section{DESCRIPTION}

Flowers: forming a long slender terminal spike; distance between flower whorls varies; floating at or near the surface

Leaves: submerged, narrowly linear; triangular in cross section; $3-10 \mathrm{~cm}$ long

Stems: slender, with many branches; extending from a slender rhizome

\section{NOTES}

Reproduction: predominantly by tubers; seeds

Habitat: may inhabit a wide range of aquatic environments from shallow, swift water to fairly deep, still water; common throughout Alberta

Ecology: may grow in overabundance, producing large quantities of organic matter in the aquatic ecosystem; important as an oxygenator; eaten by birds and aquatic orientated mammals; tubers may be heavily fed upon by ducks 


\section{Narrow-Leaved Water-Plantail}

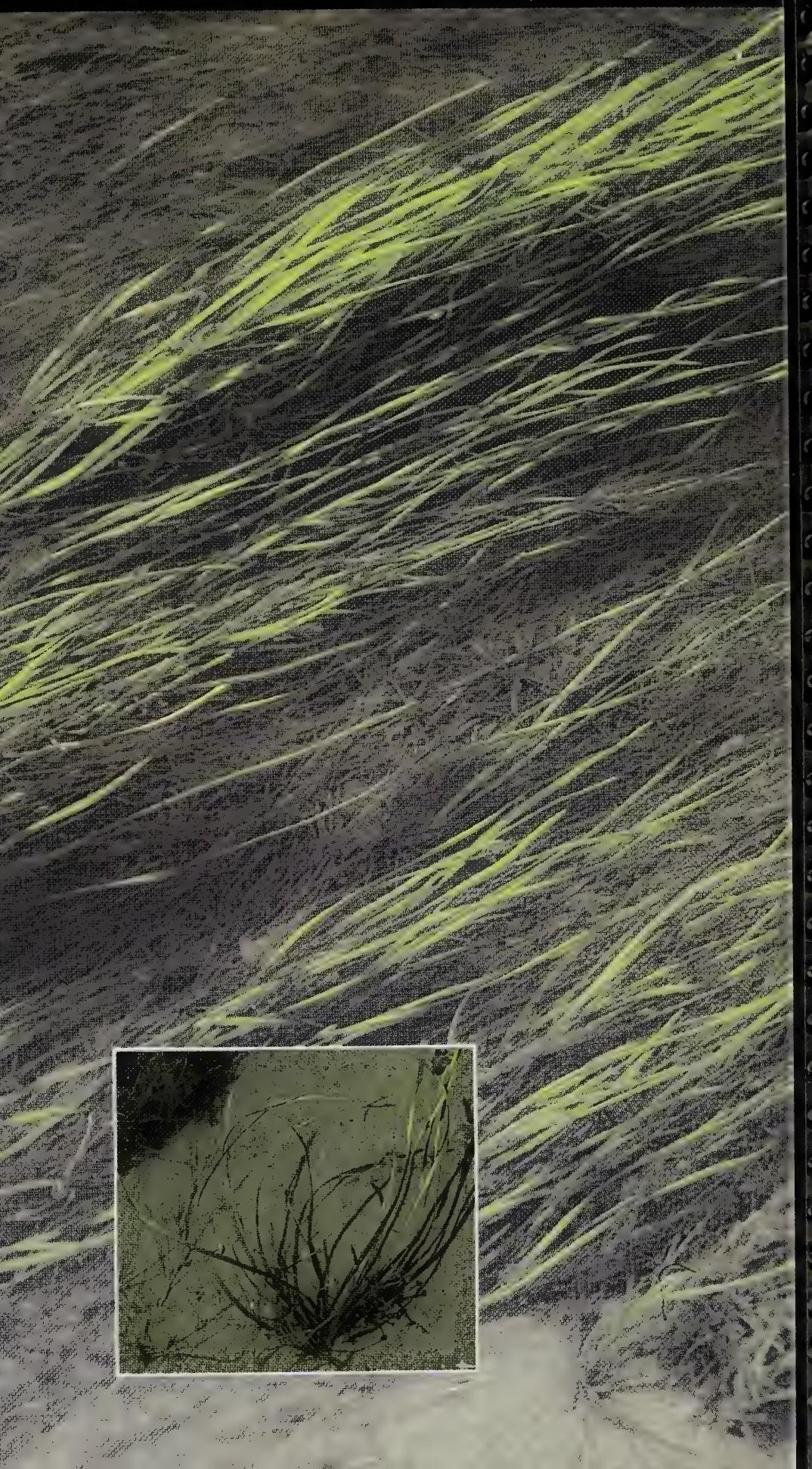




\section{Alisma gramineum Gmel.}

\section{DESCRIPTION}

Flowers: small; in clusters, at end of short spikes, attached in whorls to a long stalk from the base of the plant; flowers whitish or brownish

Leaves: long, grass-like; arising from the base of plant; in younger plants, leaves narrow and floating; in mature plants, leaves broader, with widened tips, floating or erect

Stems: bulb-like, with fibrous roots

\section{NOTES}

Reproduction: by seed or vegetatively from the perennial stem

Habitat: shallow water of ponds, sloughs, lakes, streams, ditches and canals; grows entirely submerged or emerged; common in southern Alberta

Ecology: seed used by waterfowl; prominent plant in irrigation canals 


\section{Whitestem Pondweed}
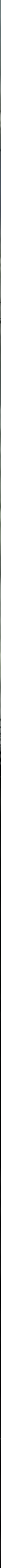


\section{Potamogeton praelongus Wulf.}

\section{DESCRIPTION}

Flowers: small, greenish; at end of a thick, emergent spike

Leaves: all submerged; large $(10-13 \mathrm{~cm}$ long, $1-3 \mathrm{~cm}$ wide); becoming smaller and crowded at end of stem; apex boatshaped; bases clasp half way around stems; persistent, long whitish stipules extend along stem from leaf base

Stems: long, branching and usually zig-zag near top; growing to surface, often forming thick surface mats; rhizomes with rusty spots

\section{NOTES}

Reproduction: from rhizomes or by seed Habitat: moderately deep water of lakes; rarely inhabiting shallow or moving water

Ecology: provides cover and foraging areas for fish; used as food by waterfowl 


\section{FLOATING LEAVED AQUATIC PLANTS}

6.0 


\section{Nuphar variegatum Engelm.}

\section{OTHER NAMES}

Spatterdock, Cowlily

\section{DESCRIPTION}

Flowers: yéllow; emerging; on long stalks; tulip-like; 4 - $7 \mathrm{~cm}$ wide

Leaves: broadly oval; 10 - $30 \mathrm{~cm}$ long; bi-lobed; long petioles (up to $4 \mathrm{~m}$ ); floating; young submersed leaves often red tinged

Stems: thick rhizomes

\section{NOTES}

Reproduction: seeds; tubers; proliferation of the rhizome

Habitat: in sheltered waters of ponds, lakes and slow moving streams throughout Alberta

Ecology: leaves eaten by deer, moose and insects; rhizome is a chief source of food for muskrat; seeds eaten by birds; floating leaves provide shade and protective cover for fish and aquatic invertebrates 


\section{Water Smartweed}

Bit.

粰:

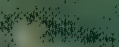

3.

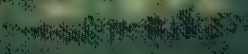

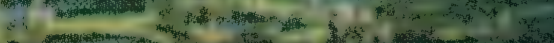

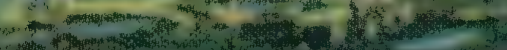

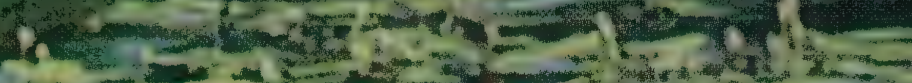

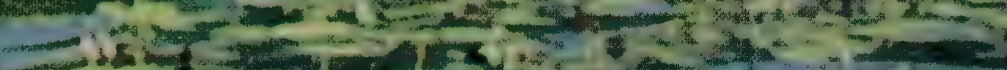

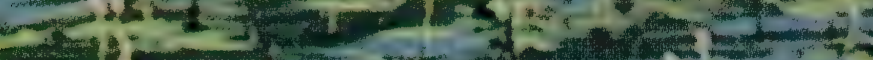

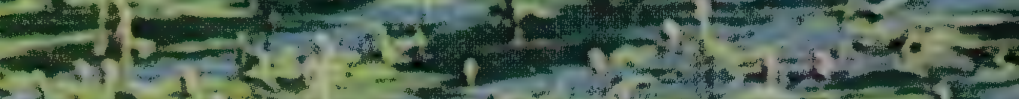

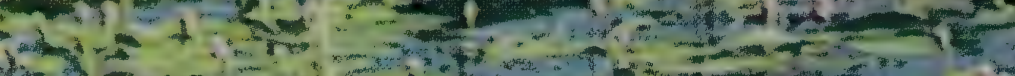

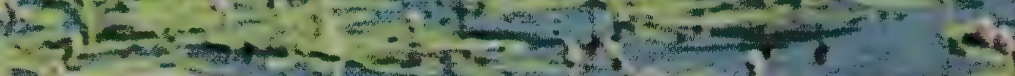

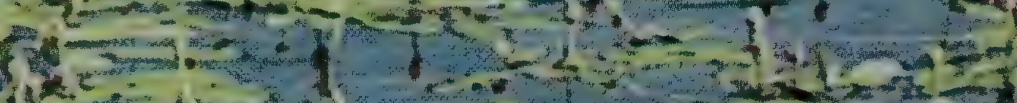

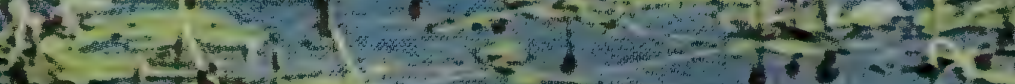
$x^{2}-1+2=5$

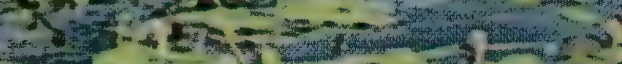

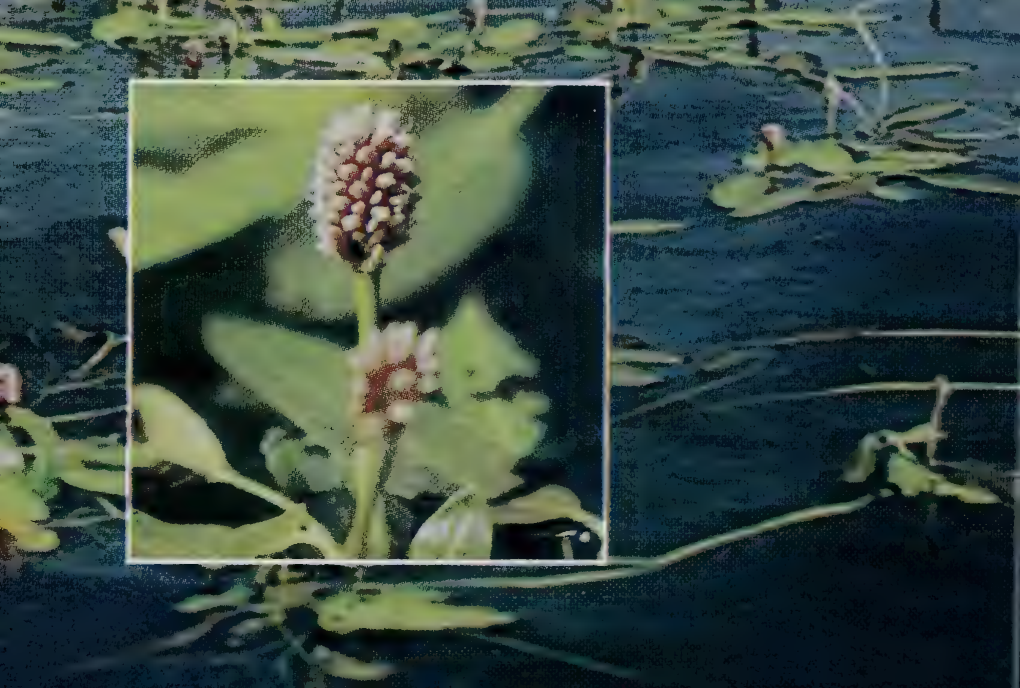




\section{Polygonum natans (Eaton)}

\section{DESCRIPTION}

Flowers: pink to red in color; emergent; in form of a raceme $1-3 \mathrm{~cm}$ long

Leaves: floating; oblong; up to $10 \mathrm{~cm}$ long; petiolate

Stems: a rhizome trailing in the water or lying on the bottom

Roots: arise from the stem nodes

\section{NOTES}

Reproduction: seeds; proliferation of the rhizome

Habitat: lakes, sloughs and marshy areas; may be seen as an erect terrestrial plant which differs in having a larger raceme, hairy stem and hairy lanceolate leaves

Ecology: used as a food source by waterfowl, shorebirds and muskrat 


\section{Floating-Leaf Pondweed}
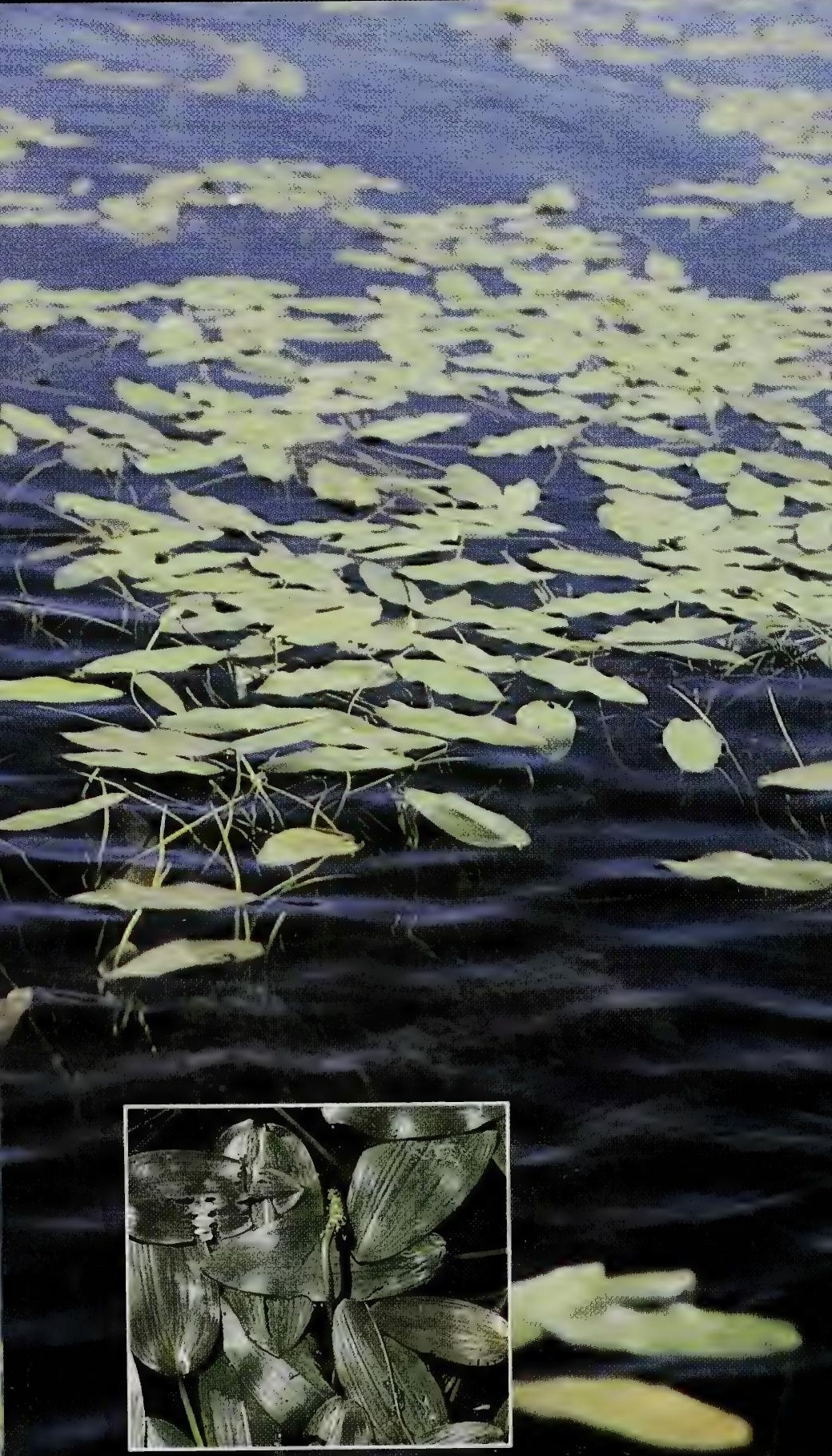


\section{Potamogeton natans L.}

\section{OTHER NAMES}

Broad-leaved Pondweed

\section{DESCRIPTION}

Flowers: small, green, numerous; on a thick, terminal, emergent spike

Leaves: numerous, broad, leathery floating leaves on petioles; occasionally long, narrow, submerged leaves up to $46 \mathrm{~cm}$ in length

Stems: rarely branched; extending from a rhizome

\section{NOTES}

Reproduction: seeds; proliferation of the rhizome

Habitat: shallow or deep water of lakes, marshes

Ecology: seeds provide food for ducks; provide cover for fish food organisms 


\section{AQUATIC PLANTS}




\section{Reed Grass}

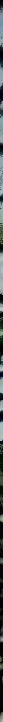

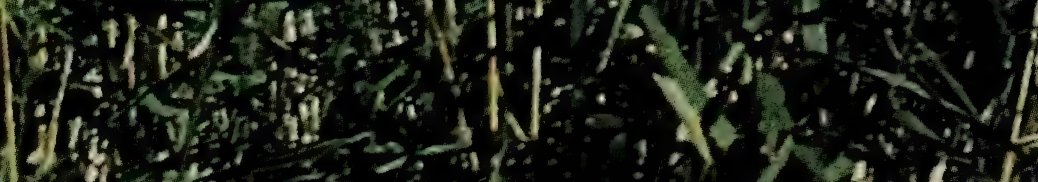

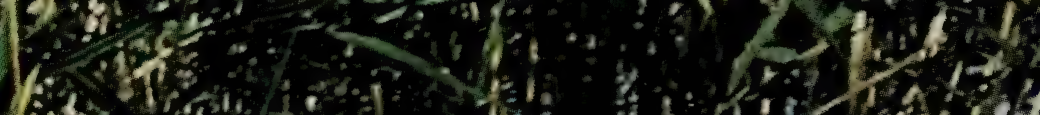

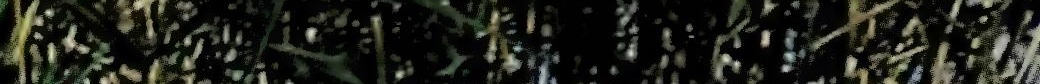
H.

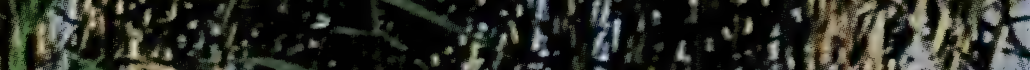

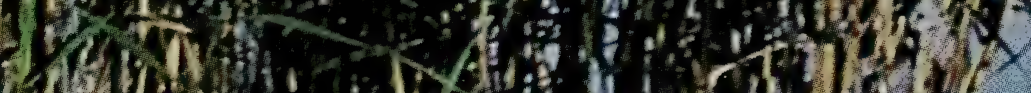

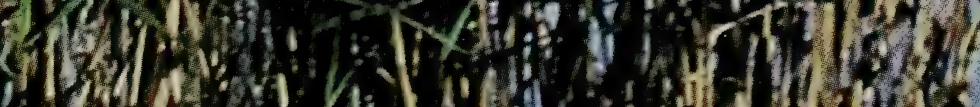
3. 0 . yor

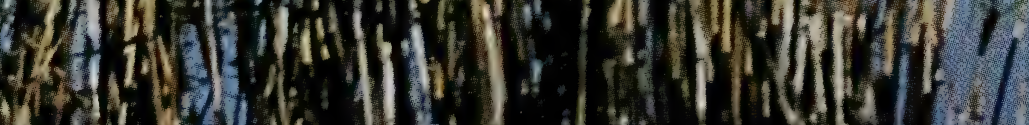

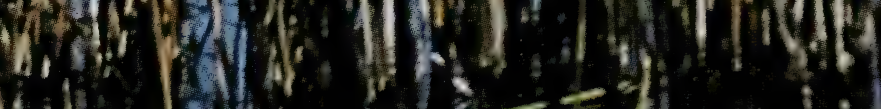
ill : An: 


\section{Phragmites communis Trin.}

\section{DESCRIPTION}

Flowers: forming a large, feathery pannicle; tawny or purple in color

Leaves: large and flat; $1-3 \mathrm{~cm}$ wide, with overlapping sheaths; tip of leaf boat-shaped

Stems: extending from thick rhizomes; $1.5-3 \mathrm{~m}$ in height

\section{NOTES}

Reproduction: seeds; proliferation of the rhizome

Habitat: quiet waters of lakes and sloughs; marshy areas and ditches

Ecology: important in providing cover for birds and small mammals; rhizomes fed upon by muskrat; helps in preventing erosion by holding the soil 


\section{Common Cattail}

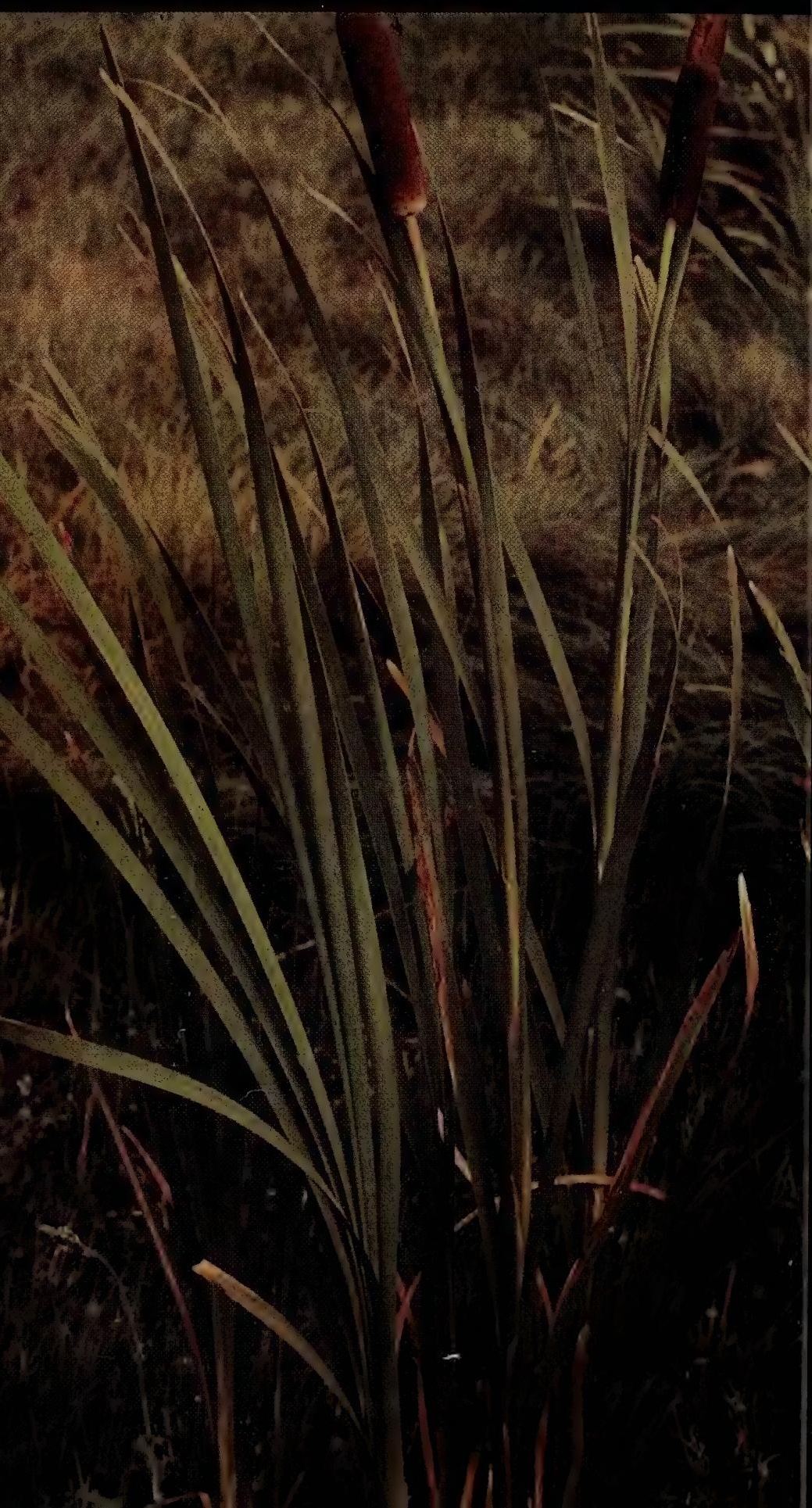




\section{Typha latifolia L.}

\section{DESCRIPTION}

Flowers: forming a dense terminal spike; unisexual; male portion of the spike produced above the thick, cigar-shaped female portion

Leaves: linear; upright, sheathing the stem; up to 1 meter long and $20 \mathrm{~mm}$ wide

Stems: growing erect; up to $2.5 \mathrm{~m}$ high; cylindrical; extending from a rhizome

\section{NOTES}

Reproduction: seeds; proliferation of the rhizome

Habitat: any wet place on marshy area; may grow on exposed soil if water table is sufficiently high (within $.5 \mathrm{~m}$ of the soil surface); prevalent in Alberta

Ecology: provides excellent habitat for birds and small mammals; pheasants use cattails for cover; rhizomes are eaten by muskrat and beaver; aerial portions may be fed upon by terrestrial mammals 


\section{Scirpus spp.}

\section{DESCRIPTION}

Identification of Bulrush species requires detailed examination of flowers and fruits.

Flowers: forming spikelets, arranged laterally or terminally on the stem; minute; in the axils of scales; flower clusters subtended by one or more bracts

Leaves: blades often lacking; when present, linear and sheathing the stem

Stems: often naked; triangular or circular in cross section, may reach $2.5 \mathrm{~m}$ in length in some species; extending from a rhizome

\section{NOTES}

Reproduction: seeds; runners; rhizomes

Habitat: shallow shoreline waters, wet meadows; distributed throughout Alberta

Ecology: bulrushes are used for food by muskrat, as nesting sites by birds and are important as soil binders 


\section{Rush}

(3)

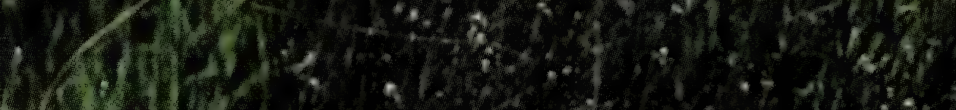

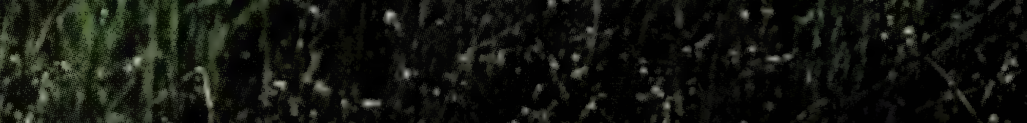

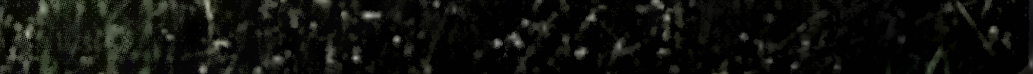
$4+40, y+4$ $\int_{\int_{4}}^{2}$ 


\section{Juncus spp.}

\section{DESCRIPTION}

Flowers: produced terminally on the stem; may appear to be lateral due to a long, cylindrical floral bract extending continuous with the stem

Leaves: may be cylindrical or flattened in cross section, or may be reduced to bladeless sheaths

Stems: in clumps or arising from a creeping rhizome; circular in cross section; $20 \mathrm{~cm}-80 \mathrm{~cm}$ in height

\section{NOTES}

Reproduction: seeds; rhizomes

Habitat: shallow water along shorelines or in wet meadows

Ecology: thickened plant bases are eaten by muskrat; seeds are eaten by upland birds 


\section{Sagittaria cuneata Sheld.}

\section{DESCRIPTION}

Flowers: in whorls of three flowers on a scape; unisexual; female flowers generally found lower on the scape; white in color

Leaves: aerial leaves sagittate; submerged leaves may be narrowly linear; petioles originate from the base of the plant; $20-40$ $\mathrm{cm}$ in height

Stems: rhizomes

\section{NOTES}

Reproduction: seeds; tubers; runners; proliferation of the rhizome

Habitat: found throughout Alberta in marshes and shallow areas or shores of lakes

Ecology: tubers are often sought after by ducks 


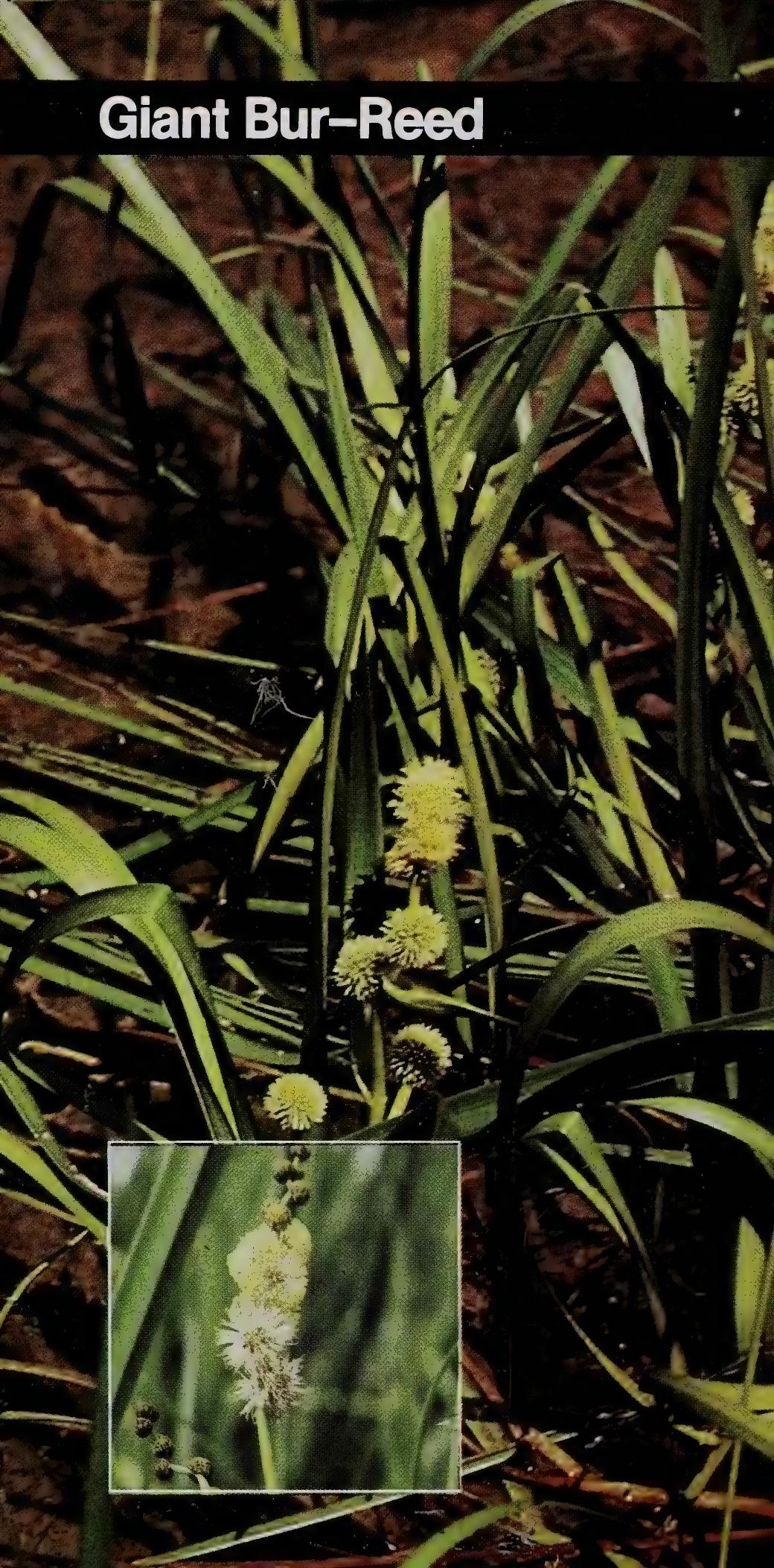




\section{Sparganium eurycarpum Engelm.}

\section{DESCRIPTION}

Flowers: unisexual; forming dense spherical heads; male flowers produced uppermost on the stem

Leaves: long, slender and sessile; longitudinal and cross veins are present on the leaves and form a meshwork pattern

Stems: sturdy, 50 - $150 \mathrm{~cm}$ high; extending from a rhizome

\section{NOTES}

Reproduction: seeds; proliferation of the rhizome

Habitat: in shallow water and marshy areas throughout Alberta

Ecology: may be fed upon by waterfowl and muskrat 


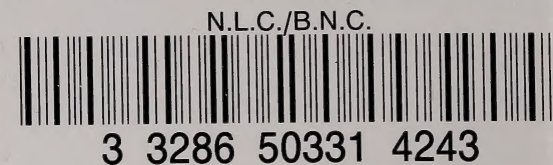

